ISSN 2651-3978 | e-ISSN 2636-8110

(Haziran/ June 2020) 19/1: 245-278

\title{
ÇAĞDAŞ Şî̂ ISLAH DüşüNCESINDE SELEFî ETKILER: ŞERÎAT SENGLECÎ ÖRNEĞi
}

\section{SALAFi EFFECTS ON CONTEMPORARY SHIITE REFORM THOUGHT: The SAMPle of SHairat SANGLajI}

\section{HABIP DEMIR}

Dr. Öğr. Üyesi, Hitit Üniversitesi, İlahiyat Fakültesi, Temel İslam Bilimleri, İslam Mezhepleri Tarihi Anabilim Dalı, Çorum, Türkiye

Asst. Prof., Hitit University, Faculty of Theology, Basic Islamic Sciences, Department of History of Islamic Sects, Çorum, Turkey

demirhabip81@gmail.com

Orcid: $0000-0003-4360-3410$

\begin{tabular}{r|l}
\hline MAKAlE Bílgisi & ARTiCLE INFORMATION \\
\hline Makale Türü & Article Type \\
\hline Araştırma Makalesi & Research Article \\
Geliş Tarihi & Date Received \\
13 Şubat 2020 & 13 February 2020 \\
Kabul Tarihi & Date Accepted \\
21 Nisan 2020 & 21 April 2020 \\
Yayın Tarihi & Published \\
30 Haziran 2020 & 30 June 2020 \\
Yayın Sezonu & Pub Date Season \\
Haziran & June \\
Doi \\
https://doi.org/10.14395/hititilahiyat.689029
\end{tabular}

Atif/Cite As:

Habip Demir, "Çağdaș Șîi Islah Düșüncesinde Selefí Etkiler: Șerîat Senglecî Örneği" [Salafi Effects on Contemporary Shiite Reform Thought: The Sample of Shairat Sanglaji], Hitit Üniversitesi Illahiyat Fakültesi Dergisi- Journal of Divinity Faculty of Hitit Üniversity, 19/1 (June 2020): 245-278.

\section{İNTIHAL/PlagiaRISM:}

Bu makale, en az iki hakem tarafından incelendi ve intihal içermediği teyit edildi. This article has been reviewed by at least two referees and scanned via plagiarism software. No plagiarism detected. Copyright (C) Published by Hitit Üniversitesi, İlahiyat Fakültesi - Divinity Faculty of Hitit University, Çorum, Turkey. All rights reserved.

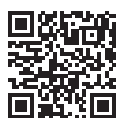

Makale dosyası

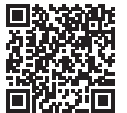

Makale ses dosyası 


\title{
Salafi Effects on Contemporary Shiite Reform Thought: The Sample of Shairat Sanglaji
}

\begin{abstract}
In the historical adventure of Islamic thought, a large number of ideas flowed, many of them disappeared in the process of time. Salafism, as a mentality and way of thinking, is an important school that influences the thought of Islam the most in the historical process and still continues to be influenced. Salafi thought, as a mentality in which a certain period of history and any information produced in that period is sanctified and all kinds of innovations and personal opinions in religious thought are perverted under names such as bid'at, superstition, not in any particular sect or school, but in every current and intellectual movement. It is a religious-political ideological phenomenon that can be seen. Although it can only be seen as a phenomenon specific to Sunni sects, it can be said that each sect has members who adopt Salafi thought. Many studies have been done about the formation, historical process and present manifestations of this mentality in Ahl al-Sunnah circles. As an umbrella concept, the Salafist mentality has deeply influenced not only Ahl al-Sunnah but also Shiite thought. It is known that the ulama has established authority in the religious field since the first centuries in Shiite thought. The emergence of benevolence and improvement movements throughout this Islamic world with modern times undoubtedly had an impact on Shiism. The effect of Salafism, which is mentioned with the revivalist movements on Shia thought, has not been subject to sufficient study yet. In accordance with the principle of deepening on individuals, our study focuses on the ideas of Shariat Sanglajî, who can be considered as the first representative of this school in Iran, by mentioning the manifestations of Salafism in Shiite in the modern period.
\end{abstract}

Keywords: History of Islamic Sects, Salafism, Shiism, Iran, Reform, Ihya, Shariat Sanglaji

\section{Summary}

A large number of ideas emerged in the historical process of Islamic thought. One of these schools is Salafism, which has a traditional religious discourse. The basic views of this school, which is formed around a large number of ideas, are based on the acceptance of all views on religion and all areas of life, especially the attributes of Allah, as in parallel with the narrations coming from the Qur'an and Rasulullah. In this context, religion has been 
imprisoned in the consciousness of a static environment in a certain period by denying all human actions such as interpretation, modification, rectification, judgment, and evaluation produced by man. The Salafist way of thinking has manifested in many ways in history until today. Numerous classification attempts have been made regarding Salafism, which differed structurally in the modern period. However, in our opinion, efforts to see the Salafism as identical to a certain school in a certain period of history, especially with the people of Ahl al-Hadith, and by emphasizing its various aspects, are not a proper approach. These classification efforts make it difficult for us to see the Salafism by isolating the original mind from its background, thus focusing on the ground that gave rise to this mentality.

As a fact, Salafism is a modern religious-political ideology that tries to shape the world with a political, social, religious, economic and tribal spirit, and adopts an apparent mindset. Although it was shaped in the Arab geography and tried to be transformed into a nationalist structure in the Sunni circles under the roof of Hanbalism and Wahabism, Salafism is a structure that transcends sects and geographies. Therefore, it is possible to be represented by different sections in every country and in all denominations.

The Shiite thought was also influenced by the Salafist mentality, which is represented in many tones in different tones. The Salafist mentality within the Shiite body should be seen as a manifestation of a modern ideology under the concepts of improvement and revival. In this context, it is possible to see the deep traces of the Salafist mentality in any kind of breeding thoughts that emerged in Shiite in parallel with the search for innovation in religion in the last century. In a sense, the call to return to the first generation brought by the Salafist mentality serves as a pivot in the criticisms of the ulama segment that has long monopolized religious thought. In this context, the emphasis on the first generation in the reform efforts that emerged in the Shiite body in the modern period also represents an anti-ulama movement.

It is known that the revivalist movements have been brought to the agenda in the context of modernizing Shiite thought for more than a hundred years in Iran. In the late 19th century, the search for innovation in the religious field that started with Shaikh Hâdî Najmâbâdî (d. 1902), who was first influenced by the Jamal al-Din al-Afghani school, continued with Shariat Sanglaji and Ahmad Kasravî (d. 1946) continued. However, despite the many criticisms directed to him, Sanglaji never broke from the Shiite tradition he was a member of and he made efforts for the benevolence of Shiite and Islam until 
the end of his life. This feature made him in a different position among the needs of his era and beyond. Our study aims to make evaluations based on his own works and his thoughts about his life and thoughts after a general perspective about the period in which Shariat Sanglaji lived.

The most important thing he focuses on is the understanding of Tawhid and the Qur'an. Sanglaji, in his work Tawhîd-i Ibâdat, which contains the obvious effects of the Wahhabi branch of Salafî thought, is considered as sacred by the Shiites and has an important place in the eyes of the people, excesses in the graves, wearing rings, etc. He discussed various issues and claimed that these thoughts had nothing to do with the practices of the Qur'an and Sunnah and then the imams. In his work titled Kilîd-i Fehm-i Kur'an, he adopted a method that prioritized the Salafist in terms of understanding the Qur'an and adopted that there would not be any place in religion in the next centuries.

When Sanglaji's thoughts are considered as a whole, it can be seen that contrary to his claim, he cannot be regarded as a reformer like Muhammad Abduh. It is seen that the Sanglaji's perception of work-centered religion that closes the doors to all kinds of new ideas with the Salafist discourse that Abduh accepted as an example in order to say a word to the perception of the modern world. It is seen that the criticisms he expressed focused on rejecting some practices represented by tradition rather than the problems of his century waiting for a solution. In this respect, it is understood that his main target was the ulama, which increased his authority in the historical process and became the dominant power in the religious field. For this reason, he wanted to give the place of charisma loaded to people in the religious field with both his works and his talks. With this discourse, it is possible to state that he acted in accordance with the main goals of Salafist thought. 


\section{Çağdaş Şiî Islah Düşüncesinde Selefî Etkiler: Şerîat Senglecî Örneği}

\section{Öz}

İslam düşüncesinin tarihi serüveninde çok sayıda fikir akımı boy göstermiş, bunların birçoğu zamanla ortadan kaybolmuştur. Bir zihniyet ve düşünüş biçimi olarak Selefîlik, tarihi süreçte İslam düşüncesini en çok etkileyen ve etkisi halen devam eden önemli bir ekoldür. Tarihin belirli bir döneminin ve o dönemde üretilen her türlü bilginin kutsallaştırılarak dinî düşüncede her türlü yeniliğin ve kişisel görüşün bid'at, hurafe gibi isimler altında sapkın görüldüğü bir zihniyet olarak Selefî düşünce, belirli bir mezhep ya da ekole has değil, her mezhep ve fikir akımında görülebilecek dinî-siyasî ideolojik bir olgudur. Her ne kadar yalnızca Sünnî mezheplere has bir olgu olarak görülüyor olsa da her mezhebin Selefî düşünceyi benimseyen mensuplarının olduğundan bahsedilebilir. Bu zihniyetin Ehl-i Sünnet çevrelerindeki oluşumu, tarihi süreci ve günümüzdeki tezahürleri hakkında hâlihazırda çok sayıda çalışma yapılmıştır. Şemsiye bir kavram olarak Selefî zihniyet, yalnız Ehl-i Sünnet'i değil, Şiî düşünceyi de derinden etkilemiştir. Şî̂ düşüncede ilk asırlardan itibaren ulemânın dinî alanda otorite kurduğu bilinmektedir. Modern dönemlerle birlikte İslam dünyasının genelinde ihya ve ıslah hareketlerinin ortaya çıkması, şüphesiz Şiîlik üzerinde de tesir bırakmıştır. İhya hareketleriyle birlikte de anılan Selefîliğin Şiî düşünce üzerindeki etkisi henüz çalışmalara konu olmamıştır. Çalışmamız, şahıslar üzerinde derinleşme prensibiyle, Selefîliğin modern dönemde Şî̂likteki tezahürlerine değinerek bu ekolün İran'da tesir bıraktığı ilk temsilcisi sayılabilecek olan Şerîat Senglecî’nin fikirlerine yoğunlaşmaktadır.

Anahtar Kelimeler: İslam Mezhepleri Tarihi, Selefîlik, Şî̂lik, İran, Reform, İhya, Şerîat Senglecî

\section{GİRIŞ}

İslam düşüncesi varlığını devam ettirdiği uzun asırlar boyunca çok sayıda bunalım dönemiyle karşılaşmıştır. Karşı karşıya kalınan bu bunalımlar İslam düşüncesinin çeşitli mecralardan beslenerek zenginleşmesine ve çeşitli coğrafyalarda temsil edilmesine olanak sağlamıştır. Bununla birlikte tarihi süreçte beşerî birikimlerin dinî düşünceye eklemlenmesi, dinin aslının ortadan kaldırılacağı şeklinde bir tehdit olarak da algılanmıştır. Böylece bir yandan İslam düşüncesi çeşitli mezhebî hareketlerle dine yönelik yeni tavırlar geliştirirken diğer yandan dini, belirli bir döneme ve o dönemin algılarına hapsetmeye çalışıp geçmişi kutsallaştırmaya çalışan akımların da gelişmesine 
zemin hazırlanmıştır. Bu düşünce biçimine günümüzde geniş anlamıyla Selefîlik adı verilmektedir. İşcan'ın "gerilemeci din söylemi" adını verdiği ve toplumda meydana gelen birtakım değişim ve gelişimlere karşı geçmişe sarılmayı öngören bu söylem, ilk ortaya çıktığı anlardan itibaren çeşitli şekillerde tezahür etmiştir. ${ }^{1}$ Doğrusu "Selefe ittiba" gibi tarihte her gelişim ve dönüşüm döneminde taraftarı olan bir tavrın ilk defa ne zaman ortaya çıktığını tespit etmek oldukça zordur. ${ }^{2}$ Ancak bu söylemin tarihi süreçte tezahürleri olarak görülen birtakım sistematik fikir ekollerinden bahsetmek mümkündür. Bu nedenle aslında modern dönemlerin bir olgusu olan Selefîliği anlayabilmek için kavramın tarihsel sürecinde beslendiği ana damarları ortaya çıkarmak ve bu ekolün tarihi köklerini temsil eden Hadis taraftarları, Hanbelîlik ve daha sonrasında İbn Teymiyye (ö. 728/1328) ile temsil edilen görüşlere kısaca değinmek gerekmektedir.

İslam düşüncesinde ilk olarak hicrî ikinci asırdan itibaren başta Re'y/Akıl olmak üzere dinde kullanılmaya başlanan yeni yöntem ve akımlara karşı çıkmayı, bu akımların yıkıcı etkilerine karşı eldeki mevcut dinî malzemeyi korumayı ve din anlayışını bu malzemelerle sınırlandırmayı ön plana alan tepki hareketine ehl-i-hadîs, ashâbu'l-hadîs, ehl-i eser gibi çeşitli isimlendirmeler yapılmış, kısaca "hadis taraftarları" olarak bilinen yeni bir ekol ortaya çıkmıştır. ${ }^{3}$ Çok sayıda fikir etrafında oluşan bu ekolün temel görüşleri, başta Allah'ın sıfatları olmak üzere dine ve hayatın bütün alanlarına dair sarf edilecek tüm görüşlerin Kur'an ve Rasulullah'tan gelen rivayetler paralelinde, olduğ gibi kabul edilmesine dayanmaktadır. ${ }^{4}$ Ancak bir süre sonra bununla da yetinilmeyerek sahabe ve tabiîn gibi ilk neslin görüş ve uygulamaları da sünnet olarak kabul edilerek din ile özdeşleştirilmiştir. İşcan'a göre böylece, insanın ürettiği yorum, değiştirme, düzeltme, yargılama, değerlendirme gibi tüm insanî eylemler inkâr edilerek din, belirli bir dönemde durağan bir çevrenin bilincine hapsedilmiştir. ${ }^{5}$

Ehl-i Hadîs ekolü, hicrî 3. asırda başlayan Mihne hadiseleri neticesinde Sünnet taraftarlığı adı altında Ahmed b. Hanbel (ö. 241/855) tarafından temsil

1 Mehmet Zeki İşcan, Selefilik: İslami Köktenciliğin Tarihi Temelleri (İstanbul: Kitap Yayınevi, 2006), 17.

2 Beşir M. Nafi, "Selefîliğin Kavram Sorunsal,, Tarihi ve Muhtelif Görünümleri", Arap Dünyasinda Selefilik ve Selefi Hareketler (İstanbul: Yarın Yayınları, 2016), 14-15; İşcan, Selefilik, 51.

3 Hadis Taraftarlarının itikadî görüşleri hakkında detaylı bilgi için bk. Sönmez Kutlu, Selefiliz̆gin Fikri Arkaplanı: İslam Düşüncesinde Illk Gelenekçiler (Ankara: Otto Yayınları, 2016), 35-79.

4 Kutlu, Hadis taraftarlarının kendi eserlerinden yola çıkarak onların görüşlerini 34 madde halinde açıklamıştır. Bk. Kutlu, Selefiliğin Fikri Arkaplanı, 74-78.

5 İşcan, Selefilik, 58-67. 
edilen Hanbelîlik ekolüne evrilerek itikadî ve f1khî bir yapıya bürünmüştür. ${ }^{6}$ Özellikle Ahmed b. Hanbel'den sonra onun görüşleri etrafında ortaya konan bu ekolün üzerinde önemle durduğu husus, her türlü fırkalaşma ve bid'atçiliğin önünü keserek hadis merkezli bir din anlayışını ikâme etmek olmuştur. ${ }^{7}$ Kavramın tarihi köklerine yapılan vurgudan hareketle "Mütekaddimûn Selefîyye" olarak da adlandırılan bu dönemin en belirgin özelliği, Kur'an, Sünnet ve Sahabe icmâının kabul edilmesi, kıyas metoduna şiddetle karşı çıkılması ve aklı itikadî söylemlerden dişlamak şeklinde tezahür etmiştir. ${ }^{8}$

Selefî düşünme biçimi, Hanbelî mezhebine mensup İbn Teymiyye ile birlikte kendisine kadarki dönemde dinî alana dair metodolojik bir ilke ya da muhafazakâr bir bakış açısı olarak kalmaktan çıkarak sistematik ve tutarlı bütünlüğe sahip bir nazariye haline gelmiştir. ${ }^{9}$ Onun ardından İbn Kayyım el-Cevziyye (ö. 751/1350) ile devam eden bu hareket 18. yüzyılda Muhammed b. Abdilvehhâb (ö. 1206/1792) ile dar kalıplar arasına sıkıştırılmış ve içtihadı tamamen reddederek yeni bir şekil almıştır. "Müteahhirûn Selefîyye" olarak da adlandırılan bu dönemde nazariyeye dair en temel eserlerin yazıldığg görülmüştür. ${ }^{10}$ Ancak bunun yanında bu dönemde Selefîliğin günümüzdeki anlamını çağrıştıracak şekilde dinî-siyasî bağımsız bir ekol olarak adlandırılmadığı, aksine ilk dönemlere ait metodolojik yaklaşıma delalet ettiği anlaşılmaktadır. ${ }^{11}$

19. yüzyıldan itibaren o güne kadar nispeten homojen bir yapı arz eden Selefî zihniyetin yeni şekillere bürünmesi, beraberinde Selefîlik ile ilgili fark11 tasnif denemelerini de getirmiştir. ${ }^{12}$ Daha çok Batılı yazarlar tarafından dile

$\overline{6}$ Hanbeliliğin itikadî bir yapıya bürünme süreci hakkında detaylı bilgi için bk. Muhyettin İğde, Siyasi-İtikadi Bir Mezhep Olarak Hanbeliliğin Teşekkül Süreci (İstanbul: Marmara Ü. İlahiyat Fakültesi Vakfı (IFAV), 2016), 106 vd.

7 Ferhat Koca, İslam Hukuk Tarihinde Selefi Söylem Hanbeli Mezhebi, 2. Bs. (Ankara: Ankara Okulu Yayınları, 2011), 121-211; İğde, Siyasi-İtikadi Bir Mezhep Olarak Hanbeliliğin Teşekkül Süreci, 185-188.

8 Mustafa Selim Yılmaz, “İslami Düşünce Tarihinde Bir Anlama Biçimi Olarak Selefîlik Üzerine Bir Deneme", Insan ve Toplum Bilimleri Araştırmaları Dergisi 3/3 (2014): 541; Nafi, "Selefîliğin Kavram Sorunsalı", 16.

9 Ferhat Koca, İslam Düşüncesinde Selefilik (Ankara: Ankara Okulu Yayınları, 2016), 16.

10 Yilmaz, "İslami Düşünce Tarihinde Bir Anlama Biçimi Olarak Selefîlik Üzerine Bir Deneme”, 542.

11 Sönmez Kutlu, "Çağdaş Araştırmalarda Mezhepleri ve Selefîliği Anlamaya Dair Sorunlar", İslam'ın Hakikati ve Mezhep Sorunu, ed. Mehmet Evkuran (Ankara: Anadolu İlahiyat Akademisi, 2016), 143; Nafi, "Selefîliğin Kavram Sorunsalı", 18-21.

12 Mehmet Ali Büyükkara, "Günümüzde Selefîlik ve İslâmî Hareketlere Olan Etkisi", Tarihte ve Günümüzde Selefilik, ed. Ahmet Kavas (İstanbul: Ensar Neşriyat, 2014), 485-524; Mehdî Fermâniyân, Cereyânş̧inâsi-yi Fikrî-Ferhengî-yi Selefìgerî-yi Muâsır (Kum: İntişârât-1 Zemzem-i Hidâyet, 1395/2016). 
getirilen Selefîliğin tasnifi ile ilgili çabalarda, dayanak noktaları açısından bazı farklılıklar bulunmaktadır. Yukarıda da kısmen değindiğimiz üzere bu düşünceyi, birçoklarının kabulüne göre doğrusal bir zaman dilimi üzerinde tarihi süreçte üç farklı dönem geçirdiğinden hareketle Mütekaddimûn, Müteahhirûn ve Yeni (Modern) Selefîlik şeklinde bir sınıflandırmaya tabi tutulduğu görülecektir. ${ }^{13}$ Ancak bu tür bir sinıflandırmanın yol açtı̆̆ 1 ve modern dönemde birbirinden oldukça farklı sâiklerin beslediği yeni hareketler karşısinda yaşanan zorluktan olsa gerek, dönemsel tasnif yerine zihniyet farkl1laşmasına dayalı tasnif modellerinin de geliştirildiği görülmüştür. Selefîliği tasnif çabaları içinde en belirgin olanlardan birine göre, Arınmacı/Tasfiyeci/ Dingin/Vaazcl, Politik ve Cihadî/Devrimci Selefîlik olmak üzere üç tezahür şeklinden bahsedilmiştir. ${ }^{14}$ Böyle bir tasnif denemesi, Selefîliğin zihniyet aç1sindan birey ve toplum üzerindeki görünürlüğü üzerinden yapılmıştır. Wiktorowicz, kendilerini siyasî herhangi bir hareket olarak görmeyerek İslam’in Selef tarafından ortaya konmuş saf halini her türlü dış etkiden korumaya yönelik çabaları "arınmacı/tasfiyeci" olarak nitelendirmektedir. ${ }^{15}$ Buna karşlık 1970'li yıllara kadar Selefî zihniyetin göreli olarak homojen bir yapı arz ettiğini, Müslüman Kardeşler hareketinin Suudî Arabistan'da etkin olmasıyla birlikte Selefîliğin siyasi olarak daha fazla iddialarla gündeme geldiğini belirtmektedir. Bu dönemin "Politik Selefîlik" olarak görülmesi gerektiğini, ${ }^{16}$ ardından 1980'li yıllarda Afganistan savaşıyla Selefîliğin yeni bir boyut kazanarak cihad merkezli düşünceler etrafında radikal bir yapıya büründüğünü ve diğer akımlar karşısında öne çıktığını ifade etmektedir. ${ }^{17}$

Her ne kadar kökleri Ehl-i Hadîs ve daha sonrasında İbn Teymiyye ve İbn Abdilvehhâb ile anılıp çeşitli tasnif denemeleri yapılsa da kanaatimizce Selefîliğin modern dönemlere ait bir kavram olarak anılması daha doğru görünmektedir. Bu olgunun yeni bir şekle bürünüp ihyâ hareketleriyle birlikte İslam dünyasında ortaya çımasında Hicaz bölgesi âlimlerinden

13 Yilmaz, "İslami Düşünce Tarihinde Bir Anlama Biçimi Olarak Selefîlik Üzerine Bir Deneme”, 541-542.

14 Quintan Wiktorowicz, "Anatomy of the Salafi Movement", Studies in Conflict \& Terrorism 29/3 (2006): 207-239; Hakan Atalay, Islahat Hareketleri ve Selefilik (Yüksek Lisans, Ankara Üniversitesi, 2016), 92. Bunun dışında Hilmi Demir de Selefîliği; Tecdit, İhya ve Yenilenme denilen kavramlar altında birleşen Islahçı Selefîlik, Kur'an'a dönüş adı altında başlatılan Entelektüel Selefîlik ve son olarak Afgan Savaşının ardından başlayan Devrimci Selefîlik adıyla üçlü bir tasnife tabi tutmuştur. Bk. Hilmi Demir, "Selefîler ve Selefî Hareketi Işid Ne Kadar Sünnidir?" (21. Yüzyıl Türkiye Enstitüsü, 2014), https://www.21yyte.org/assets/uploads/files/Selefîler\%20son.pdf. 
İbrahim b. Hasan el-Kûrânî'nin (1616-1689) ismi öne çıkmaktadır. Onun ortaya attığı yaklaşımlar öğrencileri aracılığıyla farklı bölgelere yayılmıştır. ${ }^{18}$ Ancak bu zihniyetin gözle görünür hale gelmesi, Cemâleddin Afgânî (18381897) ve Muhammed Abduh'un (1849-1905) ihyâ ve ıslah adı altında aklı ön plana çıkarıp modern eğilimlerle kavrama yeni bir boyut kazandırması ile gerçekleşmiştir. ${ }^{19} 19$ ve 20. yüzyılda ortaya çıkan bu akımın Suudî menşeli Vehhâbilik'ten belirgin farkları bulunmaktaydı. Selef'e tabi olma ve ilk neslin din anlayışını savunmanın ötesinde taklid ve hurafelerle savaşma ve modern dünyaya uyum sağlama çabaları etrafında oluşan bu eğilim, Irak'ta Mahmud Şükrü el-Âlûsî (1856-1924) ve Suriye'de Cemâleddin el-Kâsımî (1866-1914) ile temsil edilmiş ve buradan yayılma imkanı elde etmiştir. ${ }^{20} 1950$ 'li yıllardan itibaren ise petrole dayalı ekonomik gücü sayesinde Vehhâbî ideolojinin Suudî Arabistan kanalıyla daha fazla yayıldığı ve Selefîlik ile Vehhâbîliğin adeta özdeş görüldüğü gözlenmiştir. Suudî hanedanı ile görünür hale gelip Arap yarımadasında gelişme imkânı bulsa da günümüzde tüm dünyada etkisi gözle görülür şekilde artan bir eğilim haline gelmiştir. ${ }^{21}$

Selefîliğin fikrî muhtevası, ne zaman ve nasıl ortaya çıktı̆̆ı tartışmalı bir meseledir. Bu kavrama verilen tanımların, kişilerin algılarına göre değişebildiğini belirtmek gerekmektedir. Bu değişkenliği göz önüne aldığımızda, kanaatimizce Selefîliğin bir mezhep ya da başlı başına bir ekol olmadığı, çeşitli fikirleri bünyesinde barındıran bir zihniyet olması gerektiğini kabul etmek daha doğrudur. Ortaya çıkan bütün görüntüleriyle Selefîliğin aslında bir tür dinî ihya hareketi olduğu kabul edilmelidir. Dini aslına ircâyı, onu bid'atlerden temizlemeyi, mezhebî görüşlerin karmaşıklığını ve çeşitliliğini bir kenara bırakıp Kur'an ve Hadis'e dönmeyi benimseyen hareketler temelde Selefîliğin tezahürleri olarak görülmektedir. ${ }^{22} \mathrm{Bu}$ yönleriyle Selefîlik, dinde ihyâ/reform tartışmalarıyla birlikte yeniden anlam genişlemesine uğrayarak gündeme gelmiştir. ${ }^{23}$ Örneğin Abduh'a göre selefe dönme, kurumsallaşmış

18 Nafi, "Selefîliğin Kavram Sorunsalı", 21-22.

19 Hanifi Şahin, "İhya Islah Hareketleri ve Selefîlik İrtibatı", e-Makâlât: Mezhep Araştırmaları 9/1 (2016): 25-29.

20 Joas Wagemakers, "Salafism”, Oxford Religion Encyclopedias, 18 Şubat 2020, https://oxfordre. com/religion/view/10.1093/acrefore/9780199340378.001.0001/acrefore-9780199340378-e-255.

21 Beşir M. Nafi v.dğr., ed., Arap Dünyasında Selefilik ve Selefî Hareketler, trc. Nurullah Çakmaktaş (İstanbul: Yarın Yayınları, 2016); Mehmet Ali Büyükkara, Çağdaş İslami Akımlar (Klasik Yayınları, 2015), 58-82; Mazhar Tunç, Suud Selefíliği, Hadis İlmi Bağlamında Bir Araştırma (İstanbul: İz Yayıncilık, 2018); Enver Arpa, Siyasi Selefilik\&Küresel Cihad (Ankara: Eski Yeni Yayınları, 2018).

22 Nafi, "Selefîliğin Kavram Sorunsalı", 25.

23 Mehmet Zeki İşcan, “Selefîliğin İhyacıllı̆̆ ve Dini Düşüncede Yenilik", Marife 9/3 (2009): 9-10. 
dine olan bir tepkiyi ifade etmekte, insanın yaratıcı kuvvetlerini yeniden keşfederek öze ve ruha yeniden dönüş anlamına gelmektedir. ${ }^{24}$ Abduh, taklidi reddetmek, bid'atlerden dini arındırmak suretiyle toplumsal değişimi ve bunun gerektirdiği fikrî yeniliği temellendirmek istemektedir. Taklidin reddi ile birlikte insanın özgür düşüncesine bırakılan alan, Abduh tarafından, İslam'in temel inançlarına ters düşmeyen çağdaş değişimlerin gerektirdiği modern düşünce ürünleriyle doldurulmaktadır. Nitekim onun bid'atleri reddi de İslam düşüncesinde çağdaş ilmî anlayışlara uygun olmayan unsurlardan dinin temizlenmesi anlamı taşımaktadır. ${ }^{25}$ Kısaca Abduh, Selefi kutsallaştırmamış, onların dönemini bir nevi "ideal bir örneklik" olarak görmüştür. Ancak Selefî zihniyetin büyük çoğunluğu, tarihin hiçbir döneminde bu esasları Abduh'un anladığı şekilde anlamamıştır. Yapılmaya çalışılan ihyâ hareketleri, Kutlu'nun da belirttiği gibi günceli yorumlayıp kendi içinden bir ivme kazanarak İslamî düşünceyi ve sonucunda toplumu yenilemek değil, aksine, var olan sorunlardan kurtulmak için hayal edilen ve idealleştirilen Asr-ı Saâdet veya Altın Çă̆ diye tabir edilen Hz. Peygamber, Sahabe ve Tabiîn dönemindeki saflı̆̆a dönmektir. ${ }^{26} \mathrm{Bu}$ anlamıla Selefî zihniyetin temel belirleyici yönlerinden birisi, tarihi kutsallaştırarak geleneğe ilave edilen her şeyi doğru ya da yanlış olmasına bakılmaksızın reddetmektir. ${ }^{27}$ İşcan'ın "militan retçilik" olarak vasıflandırdığ $1^{28}$ bu zihniyeti Kutlu, "gelenekçi din söylemi" adıyla üst bir kavramsal okumaya tabi tutmuş ve Selefîliğin de içinde bulunduğu gelenekçi din söyleminin belli başlı hususlarda ortak kanaatler taşıdığını belirtmiştir. Bunlar arasında; akıl karşıtlı̆̆ı tutumunu benimseme, tarihe ve dinî-kültürel tecrübeye aşırı güven, metin merkezli dinî bilgi üretimi, teşbihçi (somut) düşünceyi önceleme, şekilci dindarlı̆̆ı savunma, seçilmişlik psikolojisiyle hareket etme ve pasif siyasî tutumu benimseme gösterilebilir. ${ }^{29}$

Buraya kadar anlatılanlardan yola çıkılarak Selefîliği, tarihin belli bir döneminde başta Ehl-i Hadîs olmak üzere belli bir ekolle özdeş görme ve çeşitli yönlerine vurgu yaparak tasnif etme çabalarının yerinde bir yaklaşım

24 Mehmet Zeki İşcan, Muhammed Abduh'un Dini ve Siyasi Görüşleri, 2. bs. (İstanbul: Dergah Yayinları, 1998), 225.

İşcan, "Selefîliğin İhyacıllı̆ı ve Dini Düşüncede Yenilik", 11.

Assman, tarihin kutsallaştırılması olgusunun antik dönem uygarlıklarından itibaren Ortadoğu toplumlarının neredeyse tamamında görüldügünü belirtir. Bk. Jann Assmann, Kültürel Bellek: Eski Yüksek Kültürlerde Yazı, Hatırlama ve Politik Kimlik, trc. Ayşe Tekin, 3. bs. (İstanbul: Ayrintı Yayınları, 2018), 260-267. 
olmadı̆̆ı görülmektedir. Bu tasnif çabaları, Selefîliğ́i asıl zihnî arka planından soyutlayarak görmemizi, böylece bu zihniyeti doğuran zemine odaklanmamızı güçleştirmektedir. Bir olgu olarak Selefîlik, dünyaya siyasî, toplumsal, dinî, ekonomik ve kavmiyetçi bir ruhla şekil vermeye çalışan, zâhirî düşünce biçimini benimseyen modern dinî-politik bir ideolojidir. Her ne kadar Arap coğrafyasında şekillenmiş, Hanbelîlik ve Vehhâbîlik çatısı altında Sünnî çevrelerde milliyetçi bir yapıya büründürülmeye çalışılmışsa da Selefîlik, mezhepleri ve coğrafyaları aşan ve zihniyet olarak görülmesi gereken bir yapıdır. Bu şekilde görüldüğü takdirde Selefîlik için bir coğrafya ya da zaman kesiti aramaya gerek kalmayacaktır, çünkü zihniyetlerin kontrol edilemez bir geçişkenliği söz konusudur. Dolayısıyla her ülkede ve her mezhepte farklı kesimler tarafından temsil edilebilmesi mümkündür. ${ }^{30}$

Birçok mezhepte farklı tonlarda temsil edilebilen Selefî zihniyetten Şiî düşüncesi de etkilenmiştir. ${ }^{31}$ Ancak Şiî düşüncede ortaya çıkan modern bir eğilim olan Selefî zihniyet ile kökleri erken dönemlere uzanan Ahbârîlik birbirine karıştırılmamalıdır. Şiî bünyede ortaya çıkan Ahbârîlik, Sünnî ekoldeki Ehl-i Hadîs'in metoduna benzer şekilde Kur'an ve hadislerin İmamlar kanalıyla aktarılan birikimi dışında dinde hiçbir otoriteyi kabul etmeyen kolunu temsil eder. ${ }^{32}$ Ancak Şiî bünyedeki Selefî zihniyet, 1slah ve ihyâ kavramları altında modern bir ideolojinin tezahürü olarak görülmelidir. Bu bağlamda son asırda dinde yenilik arayışları paralelinde Şî̂likte ortaya çıkan her türlü ıslah düşüncesinde Selefî zihniyetin derin izlerini görmek mümkündür. Bir bakıma Selefî zihniyetin getirdiği ilk nesle dönme çağrısı, uzun asırlardır dinî düşünceyi tekelinde tutan ulemâ kesimine yönelik yapılacak eleştirilerde bir mihver görevi görmektedir. Bu bağlamda Şiî bünyede ortaya çıkan 1slah çabalarında ilk nesle yapılan vurgu, aslında dolaylı yoldan ulemâ karşıtı bir hareketi de temsil etmektedir. ${ }^{33}$

30 Kutlu, "Çağdaş Araştırmalarda Mezhepleri ve Selefîliği Anlamaya Dair Sorunlar", 144-145; Örneğin bu olgunun İran'daki Hanefîler arasında temsili hakkında bk. Habip Demir, "Günümüz İran Hanefiliği ve İran'da Hanefilik-Maturidilik Çalışmaları", Uluslararası Şeyh Şa'bân-ı Velî Seтроzуити 2 (2017): 319.

31 Burada ve makale boyunca dile getirilen "Şiîlik" ile mezhebin en yaygın kolu olan İmâmiyye kastedilmektedir.

32 Bu düşüncenin oluşumu ve tarihî seyri hakkında detaylı bilgi için bk. Mazlum Uyar, İmamiyye Şiası'nda Düşünce Ekolleri: Ahbarilik (İstanbul: Ayışığı Kitapları, 2000); Kâsım Fâiz-Muhammed Şerîfî, "Peydâyiş, Seyr-i Tatavvur ve Tedâvum-i Ahbârîgerî", Faslnâme-i İlmî Pejûhişî-yi Kitâb-ı Kayyım 4/11 (1393/2014): 141-179; Habib Kartaloğlu, "Imamiyye'de Ahbârî-Usûlî Farklılaşması: Şeyh Saduk ve Şeyh Müfîd Örneği", Sakarya Üniversitesi İlahiyat Fakültesi Dergisi 13/24 (2011): 193-216.

33 Bu durum, modern dönem Şî̂ düşüncede ihya ya da islah faaliyetlerinin diğer İslam beldelerinde görüldüğü gibi ulemâ tarafından değil, seküler aydınlar tarafından temsil edilmiş 
İran'da yüz yılı aşkın süredir Şiî düşüncenin modernleştirilmesi bağlamında ihyacı hareketlerin gündeme geldiği bilinmektedir. 19. yüzyılın sonlarında ilk olarak Cemâleddin Afgânî ekolünden etkilenen Şeyh Hâdî Necmâbâdî (ö. 1902) ile başlayan ${ }^{34}$ ve onun öğrencisi Seyyid Esedullah Harakânî (ö. 1936) ile ilerleyen dinî alanda yenilik arayışları, sonraki nesilde Şerîat Senglecî ve Ahmed Kesrevî (ö.1946) ${ }^{35}$ ile devam etmiştir. Ancak burada Ahmed Kesrevî̀ye ayrı bir yer açmak daha doğru olacaktır. Zira Kesrevî, her ne kadar başlangıçta Şiî düşüncede bir yenilik arayışı ile ortaya çıkmışsa da ömrünün sonlarına doğru düşünceleri, adına "Pâkdinî" adını verdiği bir harekete evrilerek yeni bir din anlayışını benimsemiştir. Bu noktada Senglecî, kendisine yöneltilen çok sayıda eleştiriye rağmen mensubu bulunduğu Şiî gelenekten hiçbir zaman kopmamış ve ömrünün sonuna kadar Şî̂liğin ve İslam'ın ihyası için çaba göstermiştir. Bu özelliği, onu kendi döneminin ve sonrasının ihyacıları arasında farklı bir konuma getirmiş̧ir. ${ }^{36}$ Onu diğer sslahçılardan ayıran bir diğer özelliği ise Selefî zihin yapısından etkilenmesidir.

İran'da Selefî düşüncenin etkisi ile ilgili görebildiğimiz kadarıyla bir çalı̧̧ma bulunmamaktadır. Batı'daki bazı düşünce kuruluşlarının son yıllarda bu konuya özel verdiği görülmekte ise de Türkçe'de bu konuya doğrudan temas eden bir çalışma bulunmamaktadır. ${ }^{37}$ Çalışmamızda, şahıslarda derinleşme prensibine uygun olarak Şerîat Senglecî'nin yaşadığı döneme ilişkin genel bir

olmasıyla da yakından ilgilidir. Öyle ki bu olgu, İran'da ihya faaliyetlerinin yeterince başarı yakalamayışının da sebeplerinden birisidir. Zira İran'da ulemânın dinî otoritesi en keskin şekilde daha ilk asırlarda Kuleynî'de (ö. 329/941) yer alan rivayetlerle başlamıştır. Dolayısıyla aydın sınıfının çabaları bir gözü ulemâda olan halk nezdinde hep cılız kalmıştır. Ayrıca ulemânın ihyâ çağrıları ile aydınların çağrıları farklılıklar taşır; ulemâ geçmişe vurgu yaparken aydınlar Şiîliğin çağla barışmasına, çağdaşlaşmasına dönük çağrılar yapmıştır. Dolayısıyla ulemaya yönelik ıslah talepleri aynı zamanda Şiî düşüncenin de 1slahına dönük örtülü bir mesaj içermektedir.

34 Habip Demir, "Çağdaş Şî̂ Düşüncesinde İlk Islah Çabaları: Şeyh Hâdî Necmâbâdî (18341902)", e-Makalat Mezhep Araştırmaları 12/2 (2019): 517-545.

35 Kesrevî hakkında detaylı bir çalışma için bk. Mehmet Akif Koç, "Modernleşme Sürecinde 'İran Milliyetçiliği' Yanlısı Tebrizli Bir Aydın: Ahmed Kesrevi-Hayatı, Şahsiyeti, Dünya Görüşü, Mücadelesi ve Eserleri", Kadim Akademi SBD 3/2 (2019): 115-155.

36 Rızâ Dihkânî-Cevâd Alipûr Sîlâb, "Islahdînî-yi Dovre-i Pehlevî-yi Evvel bâ Tekye ber Ârâ-i Şerîat Senglecî", Târihnâme-i İân ba'd ez İslâm 4/7 (1392/2013): 27; Rotraud Wielandt, "Main Trends of Islamic Theological Thought from the Late Nineteenth Century to Present Times", The Oxford Handbook of Islamic Theology, ed. Sabine Schmidtke (Oxford: Oxford University Press, 2016), 734.

37 Washington Institute tarafından yapılan bir analiz için bk. Mehdi Khalaji, "The Rise of Persian Salafism", 20 Şubat 2020, https://www.washingtoninstitute.org/policy-analysis/view/ the-rise-of-persian-salafism.; Asiye Tığlı'nın daha sonra kitaplaştırılan doktora çalı̧̧ması, İran'da yenilikçi düşüncenin son dönem aydınlar üzerindeki tezâhürlerine odaklanmıştır. Bk. Asiye Tığlı, İran'da Entelektüel Dini Düşünce Hareketi (İstanbul: Mana Yayınları, 2018). 
perspektifin ardından onun hayatı ve düşünceleri hakkında kendi eserlerinden yola çıkarak değerlendirilmeler yapılacaktır.

\section{TARİHSEL ZEMIN: 20. ASRIN BAŞLARINDA IRAN'IN DINII-POLITIK DURUMU}

19. asrın ilk yarısından itibaren halkı Müslüman olan toplumlarda Batı karşısında elde edilen askerî başarısızlıklar, birtakım yenilik fikirlerinin doğmasına yol açmıştı. Önceleri bu yeniliklerin askerî ve siyasî boyutlarıyla yetinmeye çalışan Müslüman aydınlar ve devlet adamları, bunların arka planında yer alan Aydınlanma düşüncesiyle yüzleşmek zorunda kaldıklarını anlayacaklardı. Bunun neticesinde bazıları, Batı'nın ulaştığı medeniyet seviyesine ulaşmanın tıpkı onların Reform hareketleriyle yaptıkları gibi din ve dinî kurumlar ile bir hesaplaşmaya girmeden elde edilemeyeceği kanısına varmışlardı. Böylece sömürge yönetimleriyle ilk defa karşılaşan -başta Hint ve Mısır olmak üzere- İslam dünyasının birçok coğrafyasında ilerleme kavramı etrafında öncelikle dinî alanda birtakım yenilikler yapılması gerektiği fikri de oluşmuştu. Bu yenilik akımından İran'ın etkilenmemesi düşünülemezdi. ${ }^{38}$ Ancak İslam dünyasının diğer bölgelerine kıyasla İran'da modernleşme girişimleri siyasette ve toplum nezdinde önemli bir gücü elinde bulunduran ulemâ sınıfı eliyle sekteye uğratılmaktaydı. Kaçarlar döneminde (1796-1925) bu tür girişimler ulemânın izin verdiği nispette gerçekleştirilmekteydi. ${ }^{39}$

20. asrın ilk yarısı, İran toplumunun çeşitli açılardan dönüşümler yaşadığı, bu dönüşümlerin birçok alanda hissedildiği bir zaman dilimidir. 1905-1906 yılındaki Meşrutiyet hareketi, siyasî alanda birtakım dönüşümleri getirmeyi hedeflese de istenen başarıya ulaşamamış ve ülke bu ortamda ardı ardına iç çalkantılara maruz kalmıştır. 20 yıl kadar süren ve iç savaşların eşlik ettiği bunalım yıllarının ardından 1926'da iktidarı fiilen devralan ve Pehlevî hanedanı adıyla yeni bir dönemi başlatan Rıza Şah sahneye çıkmıştır. ${ }^{40}$ İran'da Rıza Şah ile başlayan bu yeni dönem, modern İran'ın kuruluşu açısından

38 19. yüzyıldaki yenilik çabaları hakkında bk. Daryuş Rahmaniyan, “Nigahî be Seyr-i Teceddud der İran (Ez Abbas Mirza tâ Emir Kebir)", Mecelle-yi Coğrafya ve Bernâmerîzî, 16 (1383/2004).

39 Kaçarlar dönemi iktidar-ulemâ ilişkileri hakkında detaylı bilgiler için bk. Mazlum Uyar, Şîิ Ulemânın Otoritesinin Temelleri (İstanbul: Kaknüs Yayınları, 2004), 179-205; Hamid Algar, Religion and State in Iran 1785-1906 : The Role of the Ulama in the Qajar Period. (Berkeley: University of California, 1969); Yılmaz Karadeniz, Kaçarlar Döneminde Iran (1795-1925) İdari, Askeri, Sosyal Yapı ve Toplumsal Hareketler (İstanbul: Selenge Yayınları, 2013); Emîr Hüseyin Hâlikînejâd, Nakş-ı Siyasi-yi Ulemâ-yı Şı̂a der Asr-ı Kâcâr (Kum: Müessese-i Bustân-ı Kitab, 1390/2011), 77 $\mathrm{vd}$.

40 Dönem hakkında detaylı bilgiler için bk. Ervand Abrahamian, Modern Iran Tarihi, trc. Dilek Şendil, 3. bs. (İstanbul: Türkiye İş Bankası Kültür Yayınları, 2014); Gene R. Garthwaite, İran tarihi : Pers Imparatorluğu'ndan Günümüze. (İstanbul: İnk1lap Kitabevi, 2011). 
önemli bir dönüm noktası olduğu gibi, aynı zamanda Şiî ulemânın Necef ve Kerbelâ olan ağırlık merkezinin İran'ın Kum şehrine geçmesi açısından da önemlidir. Böyle bir ortamda eskiden bu yana alışık olunan ulemânın etkisi nedeniyle Rıza Şah, gücü tamamen eline alamadığı iktidarının ilk yıllarında ulemânın kontrolündeki dinî ve toplumsal alan ile arasını iyi tutmaya çalışmış, bu bağlamda ulemâya saygılı davranışlarda bulunmuş ve Şiî ritüellere bizzat katılmıştır. Ancak iktidarını sağlamlaştırdıktan sonra din ve dinî kurumlarla arasına mesafe koyarak ülkenin yönünü Türkiye örneğini dikkate alarak Batı istikametine çevirmiş, yaptığı birçok yenilik hareketiyle modern bir İran toplumu yaratmaya gayret etmiştir. ${ }^{41}$ Bu dönemde yenilikler askerî, kültürel, toplumsal, hukukî ve iktisadî alanlarda yoğunlaşsa da bu yeniliklerin taşıyıcı gücü, sekülerleşme ile birlikte gelen din ve devlet arasındaki ilişkiyi belirlemeye yönelik arayışlardı. Ulemânın sahip olduğu ekonomik ve toplumsal gücü bir tehdit olarak gören Rıza Şah, öncelikle ulemâya yönelik bazı tedbirler alarak onların güçlerini kısıtlamaya ve merkezî devlete daha fazla alan açmaya gayret etmiştir. ${ }^{42}$ Bu kapsamda ulemânın kıyafetine kısıtlama getirmiş, din adamlarının devlet kurumlarında çalışmalarını yasaklamış, onların gelir getirici vakıf ve ticarî kurumlarına el koymuş, ilâhiyat eğitimi veren devlete bağlı okullar kurmuş, Hicrî takvim yerine Şemsî takvimi getirmiş ve kadınlara tesettürü yasaklamıştır. Bütün bu faaliyetlere rağmen dinî alandaki yenilenme çabalarına mesafeli yaklaşarak bu tür hareketlere doğrudan destek vermemiş, ancak bu alanda fikir beyan edenlere karşı sessiz kalmayı tercih etmiştir. Böylece Rıza Şah, doğrudan olmasa da Şiî düşünceye yönelik eleştirel tutumları olan kesimlere örtülü bir destek sağlamıştır. ${ }^{43}$

Rıza Şah’ın Batılılaşma yanlısı tutumunun Şiî düşüncede iki yansıması olduğu gözlemlenmiştir. Birincisi dine ve Şiîliğe daha çok bağlanmayı, dinî ritüellere ve dolayısıyla ulemâ sınıfına sarılmayı önceleyen muhafazakarlaşma, ikincisi ise böyle bir ortamda geçmişten gelen ulemâ sınıfının otoritesi ve mezhepteki yozlaşmalara duyulan açık eleştirilerin artmasıydı. Böylece Rıza Şah, geleneksel toplumu modern bir topluma dönüştürmeyi istemiş, neticede farklı sınıfların doğmasına yol açıldığı gibi yeni tip bir aydın modelinin

\footnotetext{
41 Mazlum Uyar, “Pehlevî Hânedanlığının Kuruluşu ve Rıza Şah Dönemi (1921-41) Devlet Ricâli-Ulemâ Münasebetleri", Din Eğitimi Araştırmaları Dergisi, 17 (2006): 175-201; Tuba Çebi, İran'da Modernleşme, Ulemâ ve İktidar: Rıza Şah Döneminde İran Devleti ve Ulemâ İlişkisi (Yüksek Lisans Tezi, Çanakkale Onsekiz Mart Üniversitesi, 2019), 158-217.

42 Muhammed Nebî Selîm, "Berhî Cereyânhâ-yı Digerendîş der Asr-1 Pehlevî", Faslnâme-i İlmî Pejûhişî̀-yi Târîh 2/6 (1386/2007): 92-93.

43

Dihkânî-Sîlâb, “Islahdînî-yi Dovre-i Pehlevî-yi Evvel”, 30.
} 
ortaya çıkmasına zemin hazırlanmıştır. ${ }^{44}$ Rıza Şah'ın uygulamaya çalıştı̆̆ modernleşme girişimleri, doğal olarak dinî düşüncede yenilik yanlılarına da fikirlerini rahatça ifade edebilme imkânı vermişti. Bu nedenle Ca'feriyan bu dönemi, siyasî, kültürel ve toplumsal alanda ulemâ aleyhindeki faaliyetlerin gözle görülür hale geldiği bir dönem olarak tasvir etmektedir. Ona göre bu dönemde sağ, sol, sosyalist gibi toplumun bütün kesimlerinin din ve ulemâ aleyhinde birleştiği, meydana gelen her türlü gerilemenin tüm faturasının din ve mezhebe kesildiği müşahede edilmiştir. ${ }^{45}$ Isşte böyle bir özgürlük ortamında Şerîat Senglecî, Ahmed Kesrevî, Ali Ekber Hakemîzâde vb. yenilik yanlılarının iktidarın örtülü koruması altında fikirlerini yaymaları olağan görülmelidir. ${ }^{46}$

\section{2. ŞERÎAT SENGLECÎ}

\subsection{Hayatı ve Eserleri}

İran'da modern dönemin sslah ve tecdid düşüncesinin en önemli kişileri arasında gösterilen ve bu nedenle "Muslih-i Kebîr" unvanıyla anılan Şerîat Senglecî'nin hayatına dair ayrıntılı bilgilere sahip değiliz. Onun ismi genellikle, İran dinî düşüncesinde "Kur'an'a dönüş hareketi”nin ilk temsilcisi ve bununla birlikte "Selefî Yeni Şiî Mektebi"nin kurucusu olarak anılmaktadır. ${ }^{47}$

Gerçek adı Muhammed Hasan Hacı Şeyh Rızâkulî Senglecî olsa da Şerîat Senglecî olarak tanınmaktadır. 1890 veya 1892'de Tahran'ın semtlerinden birisi olan Senglec'de ilmî ve kültürel mirasa sahip olan bir ailede dünyaya geldi. Doğduğu mahalle olan Senglec, Tahran'ın son yüzyılına damga vurmuş önemli şahsiyetlerin ikâmet ettiği meşhur bir yerdir. Babası Hacı Şeyh Hasan Senglecî (ö. 1931), İran'da Meşrutiyet karşıtlarının sembol ismi olarak bilinen Şeyh Fazlullah Nûrî̀nin (ö. 1909) amcasının oğludur. İsmini aldı̆̆ı dedesi Hacı Rızakulî ise kendi döneminin önde gelen ulemâsı arasında sayılmaktaydı. ${ }^{48}$

İlk eğitimini ünlü bir âlim olan babasından aldı. Bunun dişında onun fikirlerini etkileyen çok sayıda hoca bulunmaktadır. Bunların en önemlisi de Şiî düşüncesinde 1slah fikirleriyle ön plana çıkan Seyyid Esedullah

44 Ali Rıza Emînî, Tehevvolat-ı Siyasî ve İctimâ̂-yi İran der Dovrân-ı Pehlevî (Tehran: Sedâ-yı Muâsir, 1381/2002), 286.

45 Resûl Ca'feriyân, Cereyânhâ ve Sâzmânhâ-yı Mezhebî-Siyasî̀-yi Irân: Ez R̂̂-yı Kârâmeden-i Muhammed Rızâ Şah tâ Pîrûzîlyi İnkılâb-ı İslâmî, 13. bs. (Tahran: İlm, 1389/2010), 24-25.

46 Selîm, "Berhî Cereyânhâ-yı Digerendîş der Asr-1 Pehlevî”, 94.

47 Sa'd Rüstem, Zindegînâme-i Muslih-i Kebîr ve Allâme- $i$ Şehîr Âyetullah Şerîat Senglecî (İntişârât-1 Akîde, 1393/2014), 9.

48 Hüseyinkulî Müsteân, "Mukaddime”, Mahvu'l-Mevhûm, Şerîat Senglecî (Tahran: Çaphâne-i Tâbân, 1944), 4. 
Harakânî'dir. ${ }^{49}$ Hem babası Şeyh Hasan hem de Harakânî, Kaçarlar döneminde islah fikirleriyle ön plana çıkan Şeyh Hâdî Necmâbâdî'nin seçkin öğrencileri arasındadır. ${ }^{50}$ Böylece Senglecî'nin, bulunduğu çevrenin bir gereği olarak yenilikçi bir gelenek üzerine eğitim aldığ 1 konusuna kuşku yoktur. ${ }^{51}$ Rezevî, onun bu silsile ile yakın bağlarının sonucunda haklı olarak aslında her iki şahsı da etkileyen ortak bir ismin yani Cemâleddin Afgânî geleneğinin İran'daki temsilcilerinden birisi sayılması gerektiğini belirtmektedir. ${ }^{52}$

Tahran'daki ikameti sırasında çeşitli hocalardan ders alma imkânı bulan Senglecî'nin; Şeyh Muhammed Rı̂a Tunkebûnî ve Abdunnebî Müctehid Nuri'den fıkıh, Mirza Hasan Kirmanşâhî'den hikmet, Şeyh Ali Mütekellim Nuri'den kelam ve Mirza Hâşim Eşkvârî'den irfan dersleri aldığı kaydedilmektedir. ${ }^{53}$

Senglecî, henüz yirmili yaşlarında babasına ait evin avlusunda perşembe akşamları sohbet halkaları oluşturup vaazlar vermekteydi. Onun sohbetlerine büyük çoğunluğu askerler olmak üzere devlet memurlarının rağbet ettiği ifade edilmektedir. ${ }^{54}$ İlk eğitiminin ardından Şiî gelenekte yaygın bir şekilde görüldüğü üzere eğitimini ilerletmek adına 1917-1921 yılları arasında kardeşiyle birlikte Necef'te bulunmuştur. Onun Necef yılları, İngiliz işgalinin Şiî toplum üzerinde baskısının hissedildiği ve ulemâ tarafından kalkışılan İngiliz karşıtı isyan hareketlerinin en dorukta olduğu bir döneme denk gelmektedir. Senglecî'nin bu mücadelede aktif bir rol aldığına dair bir kayıt bulunmamaktadır. Ancak onun burada bulunduğu sırada adı bilinmeyen bir kitap yazdığı ve bu kitabı dönemin önde gelen taklit mercilerinden Ayetullah Muhammed Kazım Yezdî’ye sunduğu bilinmektedir. Yezdî'nin onun ilmî yeteneğini gördüğü ve bunun üzerine ona "Şerîat" unvanını verdiği bilinmektedir. ${ }^{55}$

49 Mikdad Nebevî Rezevî, "Nigâhî Tahlîlî be Tekâpûhâ-yı Fikrî-yi Şerîat Senglecî”, Faslnâme-i İmâmet Pejûhî 1/4 (1390/2011): 259; Rüstem, Zindegînâme-i Şerîat Senglecî, 27; Dihkânî-Sîlâb, "Islahdînî-yi Dovre-i Pehlevî-yi Evvel", 37.

Rezevî, “Tekâpûhâ-yı Fikrî-yi Şerîat Senglecî”, 259-260.

Şeyh Hâdî Necmâbâdî'nin düşünceleri hakkında ayrıntılı bilgi için bk. Demir, "Çağdaş Şiî Düşüncesinde İlk Islah Çabaları", 528-538.

52 Rezevî, "Tekâpûhâ-yı Fikrî-yi Şerîat Senglecî”, 260-261.

53 Nureddin Çehardehî, Vehhâbiyet ve Rîşehâa-yı Ân (Tahran: İntişârât ve Teblîgât-1 Fethî, 1363/1984), 162.

54 Çehardehî, Vehhâbiyet ve Rîşehâ-yı Ân, 159.

55 Ca' feriyân, Cereyânhâ ve Sâzmânhâ-yı Irân, 1016; Richard Yann, "Shari'at Sangalaji: a Reformist Theologian of the Rida Shah Period", Authority and Political Culture in Shiism, ed. Said Amir Arjomand (New York: State University, 1988), 162. 
Aldığı eğitimin ardından tekrar Tahran'a dönen Senglecî, babasının ilim halkalarını devam ettirerek ilmî faaliyetlerini sürdürmüştür. Bu sırada İran'da iktidarı ele geçiren Rıza Şah Pehlevî ile yakın irtibatları olduğu, hatta rejim tarafından korunup kollandığı iddia edilse de ${ }^{56}$ doğrudan rejimin yanında olmasını sağlayacak herhangi bir siyasî hareket içinde yer aldığına ya da siyasi bir makam elde ettiğine dair bir kayıt yer almamaktadır. Bu dönemde çeşitli devlet adamlarının onu ziyaret ettiği bilinmektedir. Örneğin, Adalet Bakanlığı yapan Ali Ekber Dâver, onun öğrencileri arasındaydı. Senglecî, ona Lum'atu't-Dımaşkiyye gibi klasik Şiî hukukunun "İslamî sivil hukuk" çıkartmak için sistematize edilmesi gerektiğini söyledi ve bu sözü kısmen başarıldı. ${ }^{57}$ Rıza Şah tarafından hayata geçirilmeye çalışılan modernleşme çabalarına kürsüden destek verdi. Şiîlikte acil bir reforma ihtiyaç duyulduğunu, İslam dininin modernliğe, bilime, tıbba, sinemaya, radyolara ve futbola karşı olmadığını savunurdu. ${ }^{58} \mathrm{Bu}$ yüzden olsa gerek Rıza Şah döneminde bütün geleneksel ulemâya tavır alınıp faaliyetleri yasaklanırken Senglecî́nin faaliyetlerine dokunulmamıştır. Bunun temel nedeni, Senglecî'nin yorumlarının geleneksel ulemâ sınıfına bir muhalefet olacağı, böylece aynı amaca hizmet edecek olmaları olabilir. Hatta bu amaçla onun görüşlerinden faydalanılarak hazırlanan İslam ve Rec'at adlı esere yazılan bir reddiyenin basımının devlet eliyle yasaklandığ 1 nakledilmiştir. ${ }^{59}$

1930’lu yıllardan itibaren artık olgunlaşan fikirlerini değişik çevrelerde dile getirmeye ve dikkat çekmeye başlamıştır. 1940 yılında yine Tahran'da hayırseverlerin yardımlarıyla yaptırılan Mescid-i Dâru'-t-Teblî̆g-i İslamî adı verilen yere taşınarak ölümüne kadar derslerini burada sürdürmüştür. ${ }^{60}$ Onun

56 Çehardehî, Vehhâbiyet ve Rîşehâ-yı Ân, 160; Rıza Şah'ın ilmine en çok güvendiği isimlerden biri olarak Senglecî́yi sürekli takdir ettiği bilinmektedir. Bunlardan birisinde İran'ı ziyaret eden 1913 Nobel Edebiyat ödülü sahibi Hindistanlı Rabindranath Tagore ile müzakere etmesi için bizzat Rıza Şah tarafından Senglecî seçilmiş ve yaklaşık iki saat süren münazarayı Tagore, bitirmeden terk etmiştir. Tagore, bu münazarada dinin tek olduğunu, insanların hakikati atalarından aldığı şekilde devam ettirerek bulabileceğini, böylece hak bir din aramanın gereksiz olduğunu iddia etmiş, bunun üzerine Senglecî, İslam'ın hak din olduğu konusunda delilleriyle ona cevap vermiştir. Münazaranın içeriği hakkında detaylı bilgi için bk. Çehardehî, Vehhâbiyet ve Rîşehâ-yı Ân, 166-167.

57 Yann, "Shari'at Sangalaji", 163.

58 Abrahamian, Modern Iran Tarihi, 113. Abrahamian tarafından kaynak göstermeden dile getirilen bu görüşleri Senglecî'nin eserlerinde tespit edemediğimizi belirtmek isteriz.

59 Rüstem, Zindegînâme-i Şerîat Senglecî, 133-134; Rezevî, "Tekâpûhâ-y1 Fikrî-yi Şerîat Senglecî”, 258.

60 Çehardehî, Vehhâbiyet ve Rîşehâ-yı Ân, 161. 
buradaki derslerini takip edenlerin daha çok modern eğitim almış, dışa açık, dinde yenilik arayışı içinde bulunanlar olduğu kaydedilmektedir. ${ }^{61}$

Onun hayatındaki dönüm noktalarından birisi 1939 yılında hac vazifesini yapmak üzere gittiği Mekke seyahatidir. Mekke'de Muhammed b. Abdilvehhâb ve Vehhâbî çevrelerin eserleriyle tanışarak onlardan etkilendiği, dönüşünde Tevhîd-i İbâdet ${ }^{62}$ adlı eserini yazdığı bilinmektedir. Çalışmamızda kullandığımız ve Selefî zihniyetin izlerini barındıran Tevhîd-i İbâdet adlı kitabı en önemli eserleri arasındadır. Kendisi hayattayken iki kez basılmıştır. Ölümünden sonra ise çok sayıda baskıları mevcuttur. ${ }^{63}$

Yine çalışmamızda kullandığımız Kilîd-i Fehm-i Kur'ân $n^{64}$ adlı eseri de kendisi hayattayken basılan eserleri arasındadır. Bir diğger eseri de Mahvu'l-Mev$h \hat{u} m^{65}$ adlı 41 sayfalık bir risaledir. 1944'te Tahran'da öğrencisi Hüseyinkulî Müsteân tarafından basılmıştır. Bu eserinde Senglecî, ayetlerden istifade ederek İsa, Hızır ve İlyas'ın öldüklerini ispatlamaya çalışmaktadır.

İslam ve Rec'at adlı eser, öğrencisi Abdulvehhâb Ferid Tunkebûnî tarafından onun dersleri ve beyanatlarından yararlanarak derlenmiştir. ${ }^{66}$ Ancak eserin gerek metodu gerekse içeriğinin derinliği dikkate alındığında bizzat Senglecî tarafından da yazılmış olabileceği iddia edilmektedir. ${ }^{67}$

Beyânât (Muhaderât) der Şeb-i Pençşenbe, Senglecî'nin perşembe akşamları verdiği ahlak konulu sohbetlerinin derlendiği eserdir. ${ }^{68}$

Bunların dışında onun bazı basılmayan eserleri de bulunmaktadır. Bunlar arasında, Mütesâbiât der Mesâil-i Felâsife, Yek Dovre-i Kâmil Felsefe, Telhîsu'l-Felsefe, 'Ilmu'l-Kur'ân, el-Bed' ve'l-Hurâfât ve tamamlanmayan bazı eserleri sayılabilir. ${ }^{69}$

Öğrencileri arasında Esedullah Ruîn Mübeşşirî, Abdulvehhâb Tunkebûnî, Muhammed Cevad Meşkûr, Muhammed Takî Felsefî, Hüseyinkulî Müsteân, Ali Paşa Salih ve Ahmed Ferdîd'in isimleri sayılmaktadır. ${ }^{70}$

\footnotetext{
61 Ca'feriyân, Cereyânhâ ve Sâzmânhâ-yı İân, 1017. 
1943'te Tahran'da 53 yaşında vefat etmiş ve ders verdiği mescide defnedilmiştir. $^{71}$

\subsection{Düşünceleri}

Şerîat Senglecî'nin İslam düşüncesinin birçok alanına dair görüşlerinin olduğu bilinmektedir. Ancak biz onun daha çok Şiî düşüncede geleneksel ekole itiraz ettiği, döneminde ve sonrasında aykırı olarak görülebilecek ve Selefî tezâhürler gösterdiği fikirlerine eğileceğiz.

\subsubsection{Tevhid}

Onun en çok üzerinde durduğu husus kitabına da adını veren "Tevhid" meselesidir. Tevhid, kelam ilminin ortaya çıkışından bu yana İslam düşüncesinin en temel kavramlarından birisi olmuştur. Şiî ulemâ da başlangıçtan itibaren tevhid konusuna özel bir önem vermiştir. Bu kapsamda Şiîlikte farklı adlar altında bölümlere ayrılan tevhid, genel itibariyle Uluhiyette ve İbadette Tevhid olmak üzere iki kısımda incelenmektedir. ${ }^{72}$ Senglecî de kendi döneminde Müslümanların başta tevhid olmak üzere birçok konuda yanlış yollara düştüklerini şöyle ifade eder:

"İslam nasıl garîb olmasın. Yetmiş iki belki de daha fazla fırkaya bölündü. Her biri bir şahsa tabi oldu. Ve o şahıslar da mezheplerini bid'atlerin üzerine bid'atler ekleyerek ihdas ettiler. Ardindan İslam elbiselerini bu görüşlerinin üzerine giyerek seslerini her beldede duyurabilmekteler. Birisi Allahlık iddiasında, diğeri peygamberlik, diğer biçare de velâyet ve imâmet iddiasında. Halbuki Kur'an Allah'tan başkasına itaati yasaklar."73

Senglecî, Müslümanlara bu işin doğrusunu açıklama gayreti içinde bulunacağını söyleyerek bunun ilk olarak tevhid ve ona bağlı olarak görülen alt inançların düzeltilmesinden geçtiğini belirtir. Bu bağlamda Şiî gelenektekine uygun olarak tevhid'i "Tevhid-i Rubûbiyyet" ve "Tevhid-i Ulûhiyyet ve İbâdet" olmak üzere iki kısma ayırır. ${ }^{74}$ Bunlardan birincisinin müşrikler tarafından bile kabul edilen ve üzerinde ittifak olan Allah'ın her türlü mevcudatın

71 Yann, "Shari'at Sangalaji”, 164.

72 Avni İlhan, "Şia'da Usulü'd-Din", Tarihte ve Günümüzde Şî̂lik Sempozyumu (İstanbul: İSAV Yayınları, 1993), 410; Halife Keskin, Kendi Kaynakları Işı̆̆ı̆nda Şia İnanç Esasları (İstanbul: Beyan Yayınlar1, 2000), 70.

73 Senglecî, Tevhîd-i İbâdet, 14-15.

74 Selefî gelenekte İbn Teymiyye ve onun metodunu takip eden Muhammed b. Abdilvehhab, üçlü bir tevhid sınıflandırmasını benimserler. Buna göre tevhid, tevhid-i rububiyye, tevhid-i uluhiyye (ibadet) ve tevhid-i esmâ ve sıfat olarak üçe ayrılmaktadır. Bk. Muhammed b. Abdilvehhab, Keş̧fu'ş-Şubuhât (İskenderiye: Dâru'l-İman, t.y.), 26 vd.; Ali Asgar Rıdvânî, Selefigerî (Vehhâbiyet) ve Pâsoh be Şubehât, 9. bs. (Kum: İntişârât-1 Mescid-i Mukaddes-i Cemkerân, 
yaratıcısı olduğu inancı olduğunu belirtir. ${ }^{75}$ Ancak bu sınıflandırmada asıl önemli olanın ikincisi olduğunu vurgular. Ona göre Allah'a ibadet etmenin de herkes için geçerli (âm) ve özel olmak üzere (hâs) iki boyutu bulunmaktadır. Yani, ubûdiyyeti zorunlu ve iradî olmak üzere ikili bir tasnife tabi tutar. ${ }^{76}$ Bu tevhid türünün rubûbiyyeti de kapsayan daha geniş bir çerçeve olduğunu kabul ederek tevhidin bir bütün olduğunu ve "Her kim ki Allah'ın Rasûlü, imamlar ve onların ashabına olgun bir tevhid, iman, akıl ve bilgiyle yakın olursa Allah'a yakın olur." şeklinde ifade etmiştir. ${ }^{77}$

Selefî zihniyet tarafından da sıklıkla kullanılan Tevhîd-i İbâdet (amelî tevhid) ve ona yüklenen anlamlar, aslında diğer mezheplerle arasındaki farklılığ 1 belirlemede önemli bir kıstastır. ${ }^{78}$ Şirk, Bid'at, Şefaat, Tevessül, Kabir ziyareti eleştirisi vb. Vehhâbilikle özdeş görülen fikirler amelî tevhid anlayışına yüklenen anlamlar neticesinde ortaya çıkmıştır. Bu anlayış, Allah ve Peygamberinden başkasının dinde söz sahibi olamayacağını belirten bir algıya dayanır. Böylelikle sünnetin kontrolünde okunan vahiy dışında re'y gibi insanî hususların dinde yerinin olmayacağı tek kaynaklı, tek kültürcü, tek kitapçı bir anlayışın teolojik zemini oluşturulmak istenmektedir. ${ }^{79}$ Her ne kadar amelî tevhid kavramı Şiî gelenekte kullanılsa da Senglecî bu kavramın içini Selefî öğelerle doldurmuştur.

Bunun gözle görülür en güzel örneği, amelî tevhid anlayışıyla bağlantılı olarak sıklıkla kullanılan şirk kavramıdır. Senglecî, şirki İbn Teymiyye ve Muhammed b. Abdilvehhâb'da olduğu gibi büyük ve küçük şirk olmak üzere ikiye ayırır. ${ }^{80}$ Büyük şirk, bir başka varlığa ibadet edip tapmakla olur. Küçük şirk ise, Allah'tan başkasını şefaatçi ya da rızık veren olarak görmek ya da Allah'tan başkasını belaları savıcı olarak görmek gibi kul olarak yaptığımız fiilleri Allah'tan başkasına has kılmak anlamına gelmektedir. ${ }^{81}$

1393/2014), 286; Muhammed Mücahid Dündar, Vehhâbilikte Tevhid ve Şirk (Yüksek Lisans Tezi, Marmara Üniversitesi, 2006), 29-50.

Senglecî, Tevhîd-i İbâdet, 36.

Senglecî, Kilîd-i Fehm-i Kur'ân, 191-192.

Rıdvânî, Selefigerî, 278; Dündar, Vehhâbilikte Tevhid ve Șirk, 29. İşcan, "Selefîliğin İhyacılığı ve Dini Düşüncede Yenilik", 12.

Şirk'in bu şekilde tasnifi ilk olarak Ragıb el-Isfahanî'de yer almıştır. Bk. Hüseyin b. Muhammed Ragip el-İsfahani, Müfredatu Elfazi'-Kur'ân (Beyrut: Dâru'-Kalem, 1412/1992), 452. İbn Teymiyye aynı içeriği kastetmek üzere uluhiyette ve rububiyette şirk kavramlarını kullanır. Bk. Mustafa Sinanoğlu, "Şirk", 20 Şubat 2020, https://islamansiklopedisi.org.tr/sirk.

Senglecî, Tevhîd-i İbâdet, 46. 
Bu kapsamda Şiî geleneğin temel dinamiklerinden biri olan şefaat ve tevessül inancına şiddetle karşı çıkarak Selefî-Vehhabîlerle aynı söylemi savunmuştur. Senglecî, peygamberleri, melekleri, ya da imamları günahların bağışlanması, rızık isteme, belaları defetme gibi istekler için aracı kılmanın Kur'an'ın nassı ve ümmetin icmâsıyla küfür olduğunu ifade etmektedir. ${ }^{82}$ Şefaatin ne olduğu ile ilgili fırkalar arasındaki farklara değinen Senglecî, Kur'an'a müracaat edildiğinde halk arasındaki yaygın şefaat inancının reddedildiğinin rahatlıkla görülebileceğini belirtir. Şefaatin ancak Allah'ın izniyle muvahhidler için geçerli olan sınırlı bir kavram olduğunu vurgular. ${ }^{83}$ Şefaati hak görenlerin, "padişahın nasıl ki yardımcıları var onlara arz edilir onlar da aracı olup padişaha arz ederler, böylece isteğiniz yerine gelir." şeklinde bir önermeden hareket ettiklerini belirterek, bunu diyenlerin her şeye kâdir olan, küll ve cüz'ü bilen Allah ile bir insan olan padişahı eşit tutarak tekrar kafir olduklarını söyler. ${ }^{84}$ Böyle bir söyleme sahip olanların peygamber ve imamlar zamanında dahi var olan gulat kesimlerin görüşlerini benimsediklerini söyleyerek Şiî gelenek tarafından önemli bir eser olarak kabul edilen Sahife-i Seccâdiye'den örnekler verir. ${ }^{85}$ Buna rağmen Ca'feriyan, onun şefaat konusunda sert söylemleri olduğunu ve her türlü şefaati reddettiğini belirtir. ${ }^{86}$ Ancak görüldüğü üzere onun şefaat söyleminin, Şiî gelenekte kabul edildiğinin aksine, peygamber ve imamların ne olursa olsun bütün inananlara uygulayacağ1 toplu bir şefaat olmadığ1 anlaşılmaktadır. ${ }^{87}$

Senglecî, Şiî gelenek tarafından özel önem verilen imamzâde türbeleri konusunda Vehhabîlerce dile getirilen eleştirileri aynen kabul eder. O, imamzâdelerin kutsal varlıklar olarak görüldüklerini, bu türbelere giden kişilerin onlardan yardım dilediğini, adak adandığını, oralarda bulunan ağaç, taş vb. eşyaya teberrük niyetiyle yaklaşıldığını, bu kabirlere aşırı tazim göstererek secde edildiğini, bunların tamamının Kur'an'ın kesin hükümlerine göre şirk olduğunu ifade etmektedir. Tıpkı Mekke müşriklerinin putlara yaptıkları gibi onları Allah'a aracı kıldıklarını vurgular. Senglecî́nin bu tür yorumlarını Kur'an'ın yanında el-Kâfî, Uyûnu Ahbâri'r-Rızâ gibi ilk dönem Şiî kaynaklarına dayandırdığı da özellikle belirtilmelidir. ${ }^{88}$

\footnotetext{
Senglecî, Tevhîd-i İbâdet, 116.

Senglecî, Tevhîd-i İbâdet, 132-140.

Senglecî, Tevhîd-i İbâdet, 118-119.

Senglecî, Tevhîd-i İbâdet, 125-126.

Ca'feriyân, Cereyânhâ ve Sâzmânhâ-yi İân, 1019-1020.

Tunkabûnî, İslam ve Rec'at, 244-246.

Senglecî, Tevhîd-i İbâdet, 55-70.
} 
Senglecî, kurban ibadetinin de amacından saptığını, Allah'ın adı dışında kesilen kurbanların tamamının şirk olduğunu belirtir. Bu bağlamda Hristiyanların İsa'sı ile Şiîlerin Hüseyin'ini kurban motifleri üzerinden karşılaşt1rır. Bunun yanında Şiîlerin "Ey İmamzâde" “Ey Ebü'l-Fazl”, "Ey Eimme" diyerek de kurban kestiklerini, bunların tamamının şirk olduğunu ifade eder. ${ }^{89}$

Senglecî, kabirler konusunda Vehhabîlerin aksine daha 1lımlı bir görüşü savunmaktadır. Şiî kaynaklardan aldığı rivayetlerle, kabirlerdeki her simge ve şeklin kaldırılması gerektiğini, kabirlerin yerden yükseltilmemesi ve kabirlere bina yapılmaması ve buralarda namaz kılınmadığı müddetçe Peygamber ve imamların kabirlerini ziyaret etmenin faziletli bir davranış olduğunu vurgulamaktadir..$^{90}$

Senglecî́nin Vehhabîliğin etkisinde kaldığı ve israrla vurguladığı konulardan bir diğeri de yüzük takma konusundaki hassasiyetidir. Parmağa takılan yüzükten, eve veya otomobile takılan naldan teberrük ederek ondan yardım dilemek, onları fakirlik, afet ve beladan koruduğuna inanmanın şirk olduğunu vurgulamaktadır. Şiî gelenekte yaygın bir şekilde takılan yüzüğün peygamber ve imamların örnek alınmasının bir sonucu olduğunu reddeder. ${ }^{91}$ Yine Şiî rivayetlere dayanarak peygamberin çok az bir zaman dışında yüzük takmadığını, peygamberin kullandığı yüzüğün mühür olarak kullanıldığını, teberrük için olmadığını ifade eder. İmamların da elinde yüzük olduğunu kabul eden Senglecî, bunlarda Allah'ın isimlerinin yazılı olduğunu ve bir nevi zikir için kullanıldığını, onların taşlara asla teberrük etmediklerini vurgular. ${ }^{92}$ Peygamber ve imamların bir şirk olan taşlardan teberrük etmediklerini 1srarla dile getirir. Bir taşın tıbbî olarak bazı hususiyetleri olabileceğini ama buradaki meselenin ondan gaybî olarak bir şeyler beklemek olduğunu vurgular. Kendisinin de bir yüzüğünün olduğunu ancak hac esnasında Mekke'den Medine'ye giderken bir hadis kitabının eline geçtiğini ve bu kitaptan etkilenerek elindeki yüzükten dolayı kendisini kınadığını ve onu çöle attığını

Senglecî, Tevhîd-i İbâdet, 63-67.

Senglecî, Tevhîd-i İbâdet, 150-151.

Günümüzde dahi, kendini dindar olarak tanımlayan Şiîlerin yüzük takmaya özel bir önem atfettikleri görülmüştür.

Senglecî, Şî̂ler tarafından özel önem verilen yüzük meselesinde kendi fikirlerini haklı ç1karmak adına bazı yorumlarda bulunmuştur. Bu kapsamda Şiî kaynaklarda sıkça yer alan "İmanın alameti beştir, birisi sağ parmağında yüzük olmasıdır." şeklindeki rivayeti şöyle yorumlamaktadır: "Bu, Şîa'nın alametidir. Çünkü imamlar döneminde Şiîler takiyye halinde yaşıyorlardı. Kimin Şiî olup olmadığının bir alameti yoktu. Diğerleri yüzükleri sol parmaklarına takınca, Şiîler ayırt edilsin diye imamlar sağ parmağa takılmasını istemişlerdi. Yoksa onu bir teberrük gayesiyle emretmemişlerdi." Bk. Senglecî, Tevhîd-i İbâdet, 55. 
ifade eder. ${ }^{93}$ Burada Senglecî'nin hangi eseri okuduğu belirtilmese de Vehhabîler tarafından yazılan eserlerden etkilendiği açıkça görülmektedir.

\subsubsection{Kur'an Anlayışı}

Senglecî'nin döneminde ihyâ ve islah fikirleriyle ön plana çıkmasındaki en önemli yönü onun Kur'an ile ilgili görüşleridir. Bu nedenle onu "Şiî Kur'ancılık" ekolünün İran'daki ilk ve en önemli temsilcisi olarak görenler bulunmaktadır. ${ }^{94}$ Onun görüşlerinde döneminin yaygın modern tefsir akımlarına mensup şahıslardan etkilendiği iddia edilmektedir. Bunlar arasında Muhammed Abduh, Ferid Vecdi, Tantavî gibi şahısların isimleri zikredilmektedir. Bazı yazarlar tarafından onun, Kur'an'ın asrın gereklerine uygun bir tevilinin yapılması gerektiği noktalarında modern akımların etkisinde kaldığı ifade edilmiştir. ${ }^{95}$ Ancak aksine onun görüşlerinin belirli şahısları taklit etmeye dayalı değil kendine özgü bir sisteme sahip olduğu söylenebilir.

Senglecî́nin Kur'an ile ilgili anlayışının temelinde onun anlaşılması ile ilgili problemler gelmektedir. O, Kur'an'a sonradan çeşitli mezhep taassupları neticesinde çok sayıda yorum katıldığını ve böylece onun anlamından uzaklaştırıldığını düşünmektedir. O halde yapılması gereken ilk işin Selef'in Kur'an'ı nasıl anladığını ortaya çıkarmak ve bunun sonucunda felsefe, tasavvuf ve mezhepler öncesi gerçek dini ortaya çıkarmak olduğunu vurgulamaktadır. Böylece Kur'an ona muhatap olanların anladığı şekilde anlaşılacak ve sonraki asırlarda başta ulemâ sınıfı olmak üzere dinî otoriteleri taklid terk edilecektir. ${ }^{96} \mathrm{Bu}$ yöntemde onun en önemli vurgusunun selef kavramı olduğu dikkatten kaçmamaktadır. Dinin haleften değil seleften öğrenileceğini, böylece Kur'an'ın re'ye göre tefsir edilmesinin mümkün olmadığını, bunun imamlar tarafından da bu şekilde anlaşıldığını ifade eder. ${ }^{97}$ Senglecî'nin, görüldüğü üzere, fikirlerini imamlara ve Şiî kaynaklara nispet etmek istemesiyle amacı, Şiî gelenek içinde kalarak bir ıslah talebinin olduğunu göstermektir.

93 Senglecî, Tevhîd-i İbâdet, 52-54.

94

İhsan Taberî, Senglecî’yi Rıza Şah döneminde öne çıkan üç akımdan biri olarak “Kur'an Mektebi"nin temsilcisi olarak anmaktadır. Diğer iki ekol ise, Bahâilik ve Ahmed Kesrevî'nin Pâkdînî hareketidir. Bk. İhsan Taberî, "Şerîat Senglecî", 27 Aralık 2019, http://www.rahetudeh. com/rahetude/Tabari/iran-rezashah/html/jameehiran-11.html; Ali Tasdîkî Şahrızâyî-Seyyid Rıza Müeddeb, "Nakd-i Dîdgâh-1 Reveş-i Tefsîr-i Kur'an be Kur'an, Kur'aniyân-1 Şîa”, Dovre, 28 (1393/2014): 3-4.

Selîm, “Berhî Cereyânhâ-yı Digerendîş der Asr-1 Pehlevî”, 97.

96 Senglecî, Kilîd-i Fehm-i Kur'ân, 179-180; Rüstem, Zindegînâme-i Şerîat Senglecî, 72.

97

Senglecî, Kilîd-i Fehm-i Kur'ân, 11, 53. 
Senglecî, Kur'an'a yönelik yaklaşımlarını açıkladığı müstakil eseri Kilîd-i Fehm-i Kur'an'a, birtakım Şiî çevrelerin de benimsediği tahrif iddiaları ile başlamıştır. Bazılarınca bozulmamış Kur'an'ın Ali'nin yanında olup onun eliyle İmam Zaman'a kadar ulaştığını iddia ettiklerini belirterek buna inanmanın insanları Kur'an'ın hidayet ediciliğinden uzaklaştırmak anlamına geleceğini ifade etmiştir. Ayrıca eğer böyleyse Ali'nin kendi halifeliği döneminde de eksik Kur'an'la hüküm verdiğini vs. kabul etmek gerekir ki böyle bir düşünce ona iftira anlamına gelmektedir. Aynı şekilde İmam Hasan da 6 aylık hilafeti döneminde ve Hüseyin de Kerbela'da gerçek Kur'an'ı neden göstermedi diye sorarak İmamiyye ulemâsından çeşitli kişilerin tahrif karşıtı sözlerini nakletmiştir. ${ }^{98}$

Kur'an'ın din ve şeriate dair tüm konuları kapsayan bir eğitim ve terbiye kitabı olduğunu, tüm ruh hastalıklarına şifa olup insan aklını da takviye ettiğini belirterek onun anlaşılması mümkün bir kitap olduğunu ifade eder. Ona göre, bunun için öncelikle Kur'an'ın kendisine müracaat edilmeli, ardından ahbar ile güçlendirilmelidir. Son olarak ise akıl yoluyla elde edilmiş bu bilgiler ispat edilmelidir. Ancak bunları yaparken öncelikle ayetlerin nüzûl sebepleri araştırılmalı, Arapların o günkü durumları iyi bilinmelidir. ${ }^{99}$ Senglecî burada akla vurgu yapıyor gibi görünse de onun Kur'an anlayışında aklın konumu oldukça kısıtlıdır. O, iddia edildiği gibi Kur'ancı ekolden de sayılmamalıdır. Çünkü bu ekol, Kur'an'ın tefsirinin bizzat Kur'an'ın kendisiyle olabileceğini savunan, modern bilimsel yöntemlerle Kur'an yorumunu bağdaştırmaya çalışan bir anlama biçimidir. Senglecî'nin, akıl konusunda bazı vurgular da yaptığı görülmüştür. Örneğin ona göre, "gerçek mürşid akıldır. Akletmenin önünde üç engel vardır: birincisi taklid, ikincisi büyüklere itaat ve üçüncüsü ise hevâdır." ${ }^{100}$ Ancak Senglecî'nin buradaki fikirlerinden, akla bağımsız bir rol atfetmekten ziyade mevcut ulemâ ve taklid sistemine bir itirazda bulunduğu, onun asıl hedefinin ulemâ sınıfı olduğu çıkarılabilir. Nitekim Ca'feriyan, onun eleştirilerinin doğrudan dinî düşünce ve ruhaniyet (ulemâ) kurumuna yönelik olduğunu, bu eleştirilerin dönemin iktidarı Rıza Han'ın da emelleriyle uyuştuğu için desteklendiğini belirtmektedir. ${ }^{101}$

Senglecî̀ye göre, “Kur'an'ın hükümleri küllîdir, nebinin sünneti olmadan anlaşılamaz. Itret (Ehl-i Beyt) de sünnetin beyanı olduğu için sünnet gibidir. İlm-i Kur'an'ın Ehl-i Beyt'te olması demek peygamberin sünnetinin

\footnotetext{
98 Senglecî, Kilîd-i Fehm-i Kur'ân, 18-20.

99 Senglecî, Kilîd-i Fehm-i Kur'ân, 22-39.

100 Senglecî, Kilîd-i Fehm-i Kur'ân, 170-183.

101 Ca'feriyân, Cereyânhâ ve Sâzmânhâ-yı Irân, 1018.
} 
beyanının Ehl-i Beyt nezdinde olması demektir." ${ }^{102}$ Ona göre, Kur'an'ın re'ye göre tefsiri câiz değildir. Bu konuda imamların dahi, açık bir nas ya da eser yoksa insanın kendi görüşüne göre tefsiri caiz görmediklerini ifade etmektedir. ${ }^{103}$

Senglecî, elimizdeki mevcut malzeme ile Kur'an'ın anlaşılmasının mümkün olduğunu, Şiî çevrelerde mehdî zuhur edene kadar Kur'an'i anlayamayız şeklinde bir söylemin bulunduğunu, ancak bu söylemin küfür olduğunu belirtmektedir. ${ }^{104}$ Bunun dişında sufîlerin bâtın ve zâhir ayrımı yaparak Kur'an ayetlerini kişisel müşahedelerine dayanarak anlamaya çalıştığını, ancak kendisinin böyle bir ayrıma karşı çıktığını belirtir. Senglecî, Kur'an'ın bâtın olarak görülebilecek ayetlerinin olduğunu, ancak bunların Kur'an'in maksadına yönelik olduğunu, yoksa bazılarının yaptı̆̆ı gibi bazı ayetlerin Ali'ye işaret edecek şekilde yorumlanmasının kabul edilemeyeceğini vurgulamaktadır. Bâtın olan bir yorumun doğru olması için öncelikle Arap diline ve şeriate uygun olup olmadığının dikkatli bir şekilde kontrol edilmesi gerektiğini belirtmektedir. Ancak gelenek içerisinde bazı Şî̂lerin bu tür kişisel yorumları naklettiklerini, bu bilgilerin peygamberin vahyini anlamamaktan ileri geldiğini ifade etmektedir. ${ }^{105}$ Bunu yapanların en çok dile getirdikleri hususun Kur'an'in i'cazlığı olduğunu belirten Senglecî, onun i'caz olmasının belagat ve üslubunda değil, tefekkür, tedebbür ve ilmiyle alakalı olduğunu vurgulamaktadir. ${ }^{106}$

\subsubsection{Mehdî ve Rec'at Görüşü}

Senglecî, Şiî gelenek tarafından koşulsuz olarak kabul edilen gâib imam Mehdi'nin zuhuru meselesine eserlerinde doğrudan değinmemektedir. Ondan sözlü olarak aktarılan şahitliklere dayanarak bu inancı kabul etmediği dile getirilmektedir. ${ }^{107}$ Ancak onun yöntemine ve eserlerine bir bütün olarak baktığımızda Şiî gelenekte var olduğu şekliyle bir Mehdinin geleceğini kabul ettiği, ancak onun muhaliflerini yok etmek amacıyla âhirzamanda ortaya çıkarak silahlı bir kıyamda bulunmasını reddettiğini, onun içtimaî gelişim

\footnotetext{
102 Senglecî, Kilîd-i Fehm-i Kur'ân, 41-42.

103 Senglecî, Kilîd-i Fehm-i Kur'ân, 53.

104 Senglecî, Kilîd-i Fehm-i Kur'ân, 121.

105 Senglecî, Kilîd-i Fehm-i Kur'ân, 48-52.

106 Senglecî, Kilîd-i Fehm-i Kur'ân, 150-151; Burada Senglecî’nin Şeyh Hâdî Necmâbâdî'den etkilendiği görülmektedir. Bk. Demir, “Çağdaş Şiî Düşüncesinde İlk Islah Çabaları”, 537-538.

107 Rezevî, "Tekâpûhâ-yı Fikrî-yi Şerîat Senglecî”, 254.
} 
amacıyla toplu bir kalkışmaya önderlik etmesi noktasında zuhuru savunduğunu kabul etmek daha doğru olacaktır. ${ }^{108}$

Aynı şekilde her ne kadar Şiî kaynaklarda sıkça dile getirilen ve kıyamet kopmadan bir süre önce bazı şahısların yeniden dirilmesi anlamına gelen Rec'at fikrini doğrudan reddettiğine dair bir ifade olmasa da, kendisinden sonra onun görüşlerinden etkilenerek yazıldı̆̆ eserde böyle bir inancın Kur'an ve Sünnet ekseninde kabul edilemeyeceği açıkça dile getirilmiştir. ${ }^{109}$ Burada dile getirilen görüşlerin Senglecî’ye ait olduğu, onun dönemine dair aktarılan bir rivayet kanalıyla anlaşılmaktadır. Senglecî'nin yaşadığı dönemde Kum'da yaşayan ve taklit mercii konumunda bulunan Abdulkerim Hâirî'ye, onun Rec'at'i reddettiği ile ilgili görüşlerinin hükmü sorulmuş, o da bu görüşünden dolayı onu tekfir etmenin gereksiz olduğunu belirtmiştir. Hâirî, Rec'at'ın dinin usullerinden değil furû bir mesele olduğundan hareketle, bu görüşlere sahip olduğu bilinen Senglecî'yi tekfir etmekten kaçındığ 1 kaynaklara yansımıştır. ${ }^{110}$ Hâirî, Rec'at'ın ne dinin ne de mezhebin aslından olduğunu, mükelleflerin günlük hayatını etkileyebilecek amelî bir mesele de olmadığından bahisle bu konunun gündeme getirilmemesini istemiştir. ${ }^{111}$

\subsection{Etkisi ve Ona Yönelik Eleştiriler}

Senglecî, İran'ın modernleşme sancılarının yaşandı̆̆ı ve bu nedenle birçok alanda değişimlerin ortaya çıktığ ${ }_{1}$ bir dönemde Şiî düşüncesinde birtakım 1slah fikirleriyle ön plana çıkmıştır. Ancak gerek yaşadı̆̆ı dönemde gerekse ölümünden sonra adından söz ettirmiş, hem taraftar hem de karşıt yaratma bakımından başarılı olmuştur. Onun derslerini takip edenlere bakıldı̆̆ında geleneksel ulemâ kesiminden çok asker, siyasetçi ve gazeteci gibi entelektüel çevrelere hitap ettiği görülecektir. Bunların dışındaki orta tabaka dindar kesimin geleneksel ulemâ kesiminin etkisiyle onun fikirlerinden haberdar olduğu ve ona karşı tepkili oldukları bilinmektedir. Zaten Senglecî'nin eleştirileri Şiî itikadının bizatihi kendisine yönelik değil, onun halk arasında başta ulemâ olmak üzere yaygınlaştırılan tezâhür şekillerine yöneliktir. ${ }^{112}$ Öyle ki yaşadığı döneme dair aktarılan bir anekdotta bu tesirin izleri bariz bir şekilde

\footnotetext{
108 Selîm, "Berhî Cereyânhâ-yı Digerendîş der Asr-1 Pehlevî", 98; Rüstem, Zindegînâme-i Şerîat Senglecî, 53.

109 Tunkabûnî, İslam ve Rec'at, 107-186; Ca'feriyân, Cereyânhâ ve Sâzmânhâa-yı İrân, 1017; Rüstem, Zindegînâme-i Şerîat Senglecî, 64-65.

110 Çehardehî, Vehhâbiyet ve Rîşehâ-yı Ân, 166.

111 Dihkânî-Sîlâb, "Islahdînî-yi Dovre-i Pehlevî-yi Evvel”, 42.

112 Rüstem, Zindegînâme-i Şerîat Senglecî, 50.
} 
görülmektedir. Mübâşîrî adlı bir şahsın aktardığına göre, evine misafirliğe gelen Senglecî’yi gören annesinin onun İslam düşmanı olduğu kabulüyle evi terk ettiği, hatta sofraya yemek koymaktan dahi imtina ettiği belirtilmektedir. $^{113}$

Diğer yandan o, birçoklarınca Kur'an’a ve Sünnet’e dönüş hareketini başlatarak, dini hurafelerden temizleme ve dinî düşüncenin ihyası için gayret gösteren büyük bir ıslahatçı olarak da anılmıştır. Abdurrahman Ferâmerzî onun ölümünden sonra verdiği demeçte, Senglecî'nin “İran'in Muhammed Abduh'u" belki ondan daha da iyi olduğunu, onun ancak Gazzâlî ile karşılaştırılabileceğini ifade etmektedir. ${ }^{114}$ Dahası onun "İslam Protestanlığı" akımını başlatarak özellikle Kilîd-i Fehm-i Kur'an kitabında Hristiyan Luther, Thomas ve Kalon'un mesihiyyet ile ilgili fikirlerini takip ettiği belirtilmiştir. ${ }^{115}$

Senglecî ile ilgili en çok dile getirilen eleştiri, onun dinde yenilik ve hurafelerle savaşma perdesi altında Vehhabî ideolojiyi yaymaya çalışmış olduğu iddiasıdır. ${ }^{116}$ Hatta onun bu görüşleriyle İran'da Vehhâbî akidesini Şiîlik penceresinden sunan ilk kişi olduğu iddia edilmiştir. ${ }^{117}$ Henüz hayattayken kendisine yönelik bu tür iddialardan haberdar olan Senglecî, bunun kendisine yöneltilen türlü iftiralardan biri olduğunu, kendisini bir mezhebe körü körüne tâbî biri gibi göstermek niyetinde olduklarını eserinde dile getirmiştir. ${ }^{118}$

Senglecî, geniş bir yelpazede Sünnî ve Şiî ayırt etmeksizin birçok müellifin eserinden faydalanmıştır. ${ }^{119}$ Ancak buna rağmen onun eserleri incelendiğinde ne İbn Teymiyye'nin ne de Muhammed b. Abdilvehhâb'in eserinden doğrudan alıntı olduğu görülür. Diğer yandan isim vermese de İbn Abdilvehhab'ın Kitâbu't-Tevhîd adlı eserinin içeriğinden geniş ölçüde faydalandığı görülmektedir. Eserinde gerek yöntem gerekse içerik açısından bu etkinin bariz izleri bulunmaktadır. ${ }^{120}$ Örneğin, Senglecî'nin Tevhîd-i İbâdet kitabının bazı başlıklarını birebir olarak ondan aldığı gözden kaçmamaktadır. Bunlar

\footnotetext{
113 Yann, "Shari'at Sangalaji”, 165.

114 Rüstem, Zindegînâme-i Şerîat Senglecî, 125.

115 Taberî, "Şerîat Senglecî".

116 Selîm, "Berhî Cereyânhâ-yı Digerendîş der Asr-1 Pehlevî", 96; Fâtıma Emânî Tevâî, "Şerîat Senglecî", 20 Şubat 2020, http://pajoohe.ir/\%D8\%B4\%D8\%B1\%DB\%8C\%D8\%B9\%D8\%AA-\%D8\%B3\%D9\%86\%DA\%AF\%D9\%84\%D8\%AC\%DB\%8C_a-46988.aspx; "Şerîat Senglecî", 20 Şubat 2020, https://islamhouse.com/fa/author/263776/.

117 Çehardehî, Vehhâbiyet ve Rîşehâ-yı Ân, 157.

118 Senglecî, Kilîd-i Fehm-i Kur'ân, 12.

119 Rezevî, "Tekâpûhâ-yı Fikrî-yi Şerîat Senglecî”, 269.

120 Ca'feriyân, Cereyânhâ ve Sâzmânhâ-yı İrân, 1017.
} 
arasında, "Şirkin kısımları; ağaç, taş vb. teberrük", 121 "Belaları yok etmek için yüzük, halka vb. takmak", 122 "Allah dişında kesilen adaklar", 123 "Benî âdemin enbiyâ ve sâlihler hakkındaki gulüvlerinin küfre sebep olması"124 gösterilebilir.

Her ne kadar onun doğrudan Vehhabî olduğu ve bu ideolojiyi yaymaya çalıştığ1 iddia edilse de bu etkilenmenin üst düzeyde olmayıp Senglecî'nin selef tarafından üretilen bilgiyi sorgusuz taklid etmeye yanaşmadı̆̆ının da izleri bulunmaktadır. Örneğin Mahvu'l-Mevhûm adlı eserini, Hz. İsa, İlyas ve Hızır’nn ölümsüz olduğuna dönük rivayetleri reddedip onların öldüğünü aklî ve naklî delillerle ispatlamaya adadı̆̆ı görülmektedir. Bu yöntemiyle Muhammed b. Abdilvehhâb'da görülmeyen akıl vurgusuna az da olsa sahip olduğu ve selefe ait eserleri eleştirebildiği söylenebilir. ${ }^{125} \mathrm{Bu}$ kapsamda onun da modern dönemde Şiî ulemâ arasında sıklıkla görüldüğü üzere, dinde yenilik yanlılarını halkın gözünden düşürmek için baş düşman olarak görülen Vehhabîlik ithamına maruz kaldığg söylenebilir. ${ }^{126}$ Bu tür ithamların Şiî bünye içerisinden gelen indirgemeci bir yaklaşım olduğunda kuşku yoktur. Daha önce de değinildiği üzere onun diğer yenilikçi şahsiyetlerden en önemli farkı, açıktan Şiî itikadını hedef almayan söylemiyle ıslah taleplerini Şiî kalarak yapabilmiş olmasıdır. ${ }^{127}$

$\mathrm{O}$, kendisinden sonra birçok kişiyi etkilemiştir. Ancak daha çok entelektüel kesimlere hitap etmesiyle bilinen Senglecî́nin, diğerlerinden farklı olarak ulemâ sınıfına mensup olup en etkili öğrencilerinden birisi olarak gösterilen Hakemîzâde'nin, onun görüşlerini Kum Havzası'nda yaymak için "Humâyûn" adlı bir gazete çıkardığı, ancak bu gazetenin yoğun baskılara dayanamayarak 12 sayının ardından yayın hayatına son verdiği bilinmektedir. Bunun üzerine Hakemîzâde, görüşlerini Esrâr-ı Hezârsâle adlı çok ses getiren bir kitap aracılığıyla dile getirmiştir. ${ }^{128}$ Bu kitaba ve dolayısıyla Senglecî'nin fikirlerine, Ayetullah Humeynî tarafından Keşfu'l-Esrâr adlı bir reddiye yazılarak cevap verilmeye çalışılmıştır.

\footnotetext{
121 Muhammed b. Abdilvehhâb, Kitâbu't-Tevhîd, 5. bs. (Kuveyt: Mektebetu Ehli'1-Eser, 1435/2014), 149-153.

122 İbn Abdilvehhâb, Kitâbu't-Tevhîd, 141-142.

123 İbn Abdilvehhâb, Kitâbu't-Tevhîd, 154-157.

124 İbn Abdilvehhâb, Kitâbu't-Tevhîd, 187-188.

125 Dihkânî-Sîlâb, "Islahdînî-yi Dovre-i Pehlevî-yi Evvel”, 96.

126 Rüstem, Zindegînâme-i Şerîat Senglecî, 11.

127 Rüstem, Zindegînâme-i Şerîat Senglecî, 135.

128 Dihkânî-Sîlâb, "Islahdînî-yi Dovre-i Pehlevî-yi Evvel”, 33.
} 
Onun fikirlerini etkilediği diğer kişiler arasında; Abdulhüseyin Âyetî, Abdurrahman Bedîüzzamânî Kürdistânî, Mühendis Mehdî Bazergân, Hacı Mirza Yusuf Şîar Tebrîzî, Ali Ekber Hakemîzâde, Doktor Abbas Ziryâb Hûî, Doktor Seyyid Sâdık Takavî, Murtaza Müderrisî Çehardehî, Mühendis İzzetullah Sehâbî, Haydar Ali Kalemderân gibi siyaset ve entelektüel kesimlerden şahısların isimleri zikredilmektedir. ${ }^{129}$

\section{SONUÇ}

İslam düşüncesinin tarihi sürecinde çeşitli fikir akımları ve ekoller ortaya çıkmıştır. Bu ekollerden bazıları bulundukları dönemin sınırlarını aşarak kendisinden sonra nesiller boyu İslam toplumunun düşünce hayatını etkilemeye devam etmiştir. Bunlar arasında günümüzde en çok etkili olanların başında Selefî düşünme biçimi ye almaktadır. İslam tarihinin ilk asrındaki mevcut birikimin dinî düşüncede belirleyici bir unsur olarak kabul edildiği bu düşünme biçimi, tarih boyunca çeşitli toplumlar tarafından üretilmiş her türlü bilgiye sapkın olarak bakıp dini, ilk dönemin saflığına ve berraklığına döndürmeyi amaçlamıştır. Hicrî ikinci asırdan itibaren Ehl-i Hadîs ve daha sonrasında Hanbelî mezhebince bayraktarlı̆̆1 yapılan bu zihniyetin metodolojik bir yapıya bürünmesi, İbn Teymiyye ile gerçekleşmiştir. Ardından Arap yarımadasında 18. yüzyılın ortalarında Muhammed b. Abdilvehhâb'ın faaliyetleriyle Vehhâbîlik adı altında bu olgu daha çok gündeme gelmiştir. Bu zihniyetin temel görüşleri, ilk neslin din anlayışına dönerek dinde sonradan ortaya çıkan bid’at ve hurafelerle mücadele etmek üzerine temellendirilmiştir.

19. yüzyıla gelindiğinde İslam dünyasının içinde bulunduğu yıkıcı duruma bir çare aramak amacıyla çeşitli coğrafyalarda ihyâ ve ıslah düşüncesi temelinde dinî alana çekidüzen vererek İslam'ı yeniden hâkim kılma amaçlı düşünceler üretilmiştir. Bu düşünceler, ilk dönemlerden itibaren etkisini sürdüren selefe ittibâ söylemini esas alarak, zaman içerisinde ortaya çıkmış her türlü otoriteye bir nevi meydan okuma aracı olarak kullanılmıştır. Yani, modern dönemde ortaya çıkan ve adına Selefîlik denilen hareket, sınırları belirli bir mezhep olmaktan öte çeşitli motivasyonları olan, esasında dinî-politik bir ideolojik söylem olarak belirmiştir. Bu bağlamda Selefî zihniyeti, her ne kadar geçmişte bazı tezahürleri bulunsa da modern zamanlara özgü bir olgu olarak görmek daha isabetlidir.

İdeolojik bir söylem olarak Selefî zihniyet, her ne kadar Sünnî çevrelerde belirginleşse de belirli bir mezhebin ürünü değil, her mezhepte ve ekolde

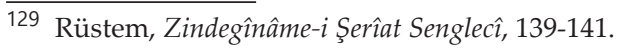


temsil edilebilen mezhepler üstü bir düşünce birikimidir. Bu düşünceden hareketle çalışmamız Selefî zihniyetin çağdaş dönem Şiîliğin ünlü simâlarından Şerîat Senglecî'nin fikirlerine yoğunlaşmış ve bu zihniyetin Şiî düşüncedeki tesirlerinin izini sürmüştür.

20. yüzyılın başları İran için oldukça çalkantılı bir dönem olmuş, iktidarı ele geçiren Rıza Şah ile birlikte modernleşme girişimleri hız kazanmıştır. Bu dönemde Rıza Şah tarafından her alanda olduğu gibi din alanında da bazı reformlar yapılmış, ulemânın özellikle ekonomik etkinliği kırılmaya çalışılmıştır. Böyle bir dönemde saygın bir çevrede dünyaya gelen Şerîat Senglecî, ulemânın mevcut otoritesine adeta meydan okuyarak geleneksel Şiî düşüncesinin dokunulamayan alanlarında 1slah fikirlerini yaymıştır. Bu yönüyle o, birçoklarınca dinde reform düşüncesinin İran'daki en etkili sesi olarak kabul edilmiştir.

Senglecî, Selefî düşüncenin Vehhâbî kolunun bariz etkilerini barındıran Tevhîd-i İbâdet adlı eserinde Şiîler tarafından kutsal olarak görülen ve halk nazarında önemli yeri olan taklid düşüncesi, kabir ziyaretlerindeki aşırılıklar, yüzük takmak vb. çeşitli konuları ele almış ve bu düşüncelerin Kur'an ve Sünnet, ardından imamların uygulamalarıyla ilgisinin bulunmadığını iddia etmiştir. Yine Kilîd-i Fehm-i Kur'an adlı eserinde ise, Kur'an'ın anlaşılması bakımından Selef'i önceleyen bir metodu benimsemiş, sonraki asırlarda ulemâ tarafından ortaya konan her türlü tefsirin dinde yerinin olmayacağını benimsemiştir.

Senglecî'nin düşüncelerine bir bütün olarak bakıldı̆̆ında, onun iddia edildiğinin aksine Muhammed Abduh benzeri bir reformcu sayılamayacağı açıkça görülmektedir. Abduh'un modern dünyanın algısına söz söyleyebilmek adına bir örneklik olarak kabul ettiği Selef söylemiyle, Senglecî'nin her türlü yeni fikre kapıları kapatan eser merkezli din algısının birbirinden oldukça farklı olduğu görülmektedir. Onun dile getirdiği eleştiriler, kendi asrının çözüm bekleyen sorunlarından çok, gelenek tarafından temsil edilen bazı uygulamaları reddetmeye odaklanmıştır. Bu yönüyle onun asıl hedefinin tarihî süreçte otoritesini arttıran ve dinî alanda egemen güç haline gelen ulemâ sınıfı olduğu anlaşılmaktadır. Bu nedenle gerek eserleri ve gerekse sohbetleriyle dinî alanda kişilere yüklenen karizmanın yerini esere vermek istemiştir. Bu söylemiyle onun, Selefî düşüncenin temel amaçlarına uygun şekilde hareket ettiğini belirtmek mümkündür. Bunu yaparken diğer taraftan selef tarafından üretilen her türlü bilgiyi de kutsallaştırma yoluna gitmeyerek Nüzûl-i İsa vb. konularda geleneğin ürettiği bilgiyi sorunlu görmüştür. 
Her halükârda Senglecî'nin, akîdelerin Kur'an'la belirleneceği ve Selefîn birikimiyle teyit edileceğine olan vurgusu, Şiî düşüncede yenilik yanlılarını teşvik etmiş, kendisinden sonra onun açtığ1 yolda halen de devam eden islah çabaları için bir mihenk noktası işlevi görmüştür.

\section{KAYNAKÇA}

Abrahamian, Ervand. Modern Irran Tarihi. Trc. Dilek Şendil. 3. Basım. İstanbul: Türkiye İş Bankası Kültür Yayınları, 2014.

Algar, Hamid. Religion and State in Iran 1785-1906 : The Role of the Ulama in the Qajar Period. Berkeley: University of California, 1969.

Arpa, Enver. Siyasi Selefilik \& Küresel Cihad. Ankara: Eski Yeni Yayınları, 2018.

Assmann, Jann. Kültürel Bellek: Eski Yüksek Kültürlerde Yazı, Hatırlama ve Politik Kimlik. Trc. Ayşe Tekin. 3. Basım. İstanbul: Ayrıntı Yayınları, 2018.

Atalay, Hakan. Islahat Hareketleri ve Selefilik. Yüksek Lisans, Ankara Üniversitesi, 2016.

Büyükkara, Mehmet Ali. Çă̆daş İslami Akımlar. İstanbul: Klasik Yayınları, 2015.

Büyükkara, Mehmet Ali. "Günümüzde Selefîlik ve İslâmî Hareketlere Olan Etkisi". Tarihte ve Günümüzde Selefilik. Ed. Ahmet Kavas. 485-524. İstanbul: Ensar Neşriyat, 2014.

Ca'feriyân, Resûl. Cereyânhâ ve Sâzmânhâ-yı Mezhebî-Siyasî-yi İân: Ez R̂̂-yı Kârâmeden-i Muhammed Rızâ Şah tâ Pîrûzî-yi İnkılâb-ı İslâmî. 13. Basım. Tahran: İlm, 1389/2010.

Çebi, Tuba. İran'da Modernleşme, Ulemâ ve İktidar: Rıza Şah Döneminde İran Devleti ve Ulemâ İlişkisi. Yüksek Lisans, Çanakkale Onsekiz Mart Üniversitesi, 2019.

Çehardehî, Nureddin. Vehhâbiyet ve Rîşehâ-yı Ân. Tahran: İntişârât ve Teblîgât-1 Fethî, 1363/1984.

Demir, Habip. “Çağdaş Şiî Düşüncesinde İlk Islah Çabaları: Şeyh Hâdî Necmâbâdî (1834-1902)”. e-Makalat Mezhep Araştırmaları 12/2 (2019): 517-545. https://doi.org/10.18403/emakalat.652337.

Demir, Habip. “Günümüz İran Hanefiliği ve İran'da Hanefilik-Maturidilik Çalışmaları”. Uluslararası Şeyh Şa'bân-ı Velî Sempozyumu 2 (2017): 312-324.

Demir, Hilmi. “Selefîler ve Selefî Hareketi Işid Ne Kadar Sünnidir?” 21. Yüzyıl Türkiye Enstitüsü, 2014. https://www.21yyte.org/assets/uploads/files/Selefîler\%20son.pdf.

Dihkânî, Rızâ-Sîlâb, Cevâd Alipûr. "Islahdînî-yi Dovre-i Pehlevî-yi Evvel bâ Tekye ber Ârâ-i Şerîat Senglecî”. Târihnâme-i İrân ba'd ez İslâm 4/7 (1392/2013): 25-50.

Dündar, Muhammed Mücahid. Vehhâbilikte Tevhid ve Şirk. Yüksek Lisans, Marmara Üniversitesi, 2006.

Emînî, Ali Rıza. Tehevvolat-ı Siyasî ve İctimâ̂-yi İran der Dovrân-ı Pehlevî. Tehran: Sedâ-yı Muâsır, $1381 / 2002$.

Fâiz, Kâsım-Şerîfî, Muhammed. "Peydâyiş, Seyr-i Tatavvur ve Tedâvum-i Ahbârîgerî". Faslnâme-i İlmî Pejûhişî-yi Kitâb-ı Kayyım 4/11 (1393/2014): 141-179.

Fermâniyân, Mehdî. Cereyânşinâsi-yi Fikrî-Ferhengî-yi Selefígerî-yi Muâsır. Kum: İntişârât-1 Zemzem-i Hidâyet, 1395/2016. 
Garthwaite, Gene R. İran tarihi : Pers İmparatorluğu'ndan Günümüze. İstanbul: İnkılap Kitabevi, 2011.

Hâlikînejâd, Emîr Hüseyin. Nakş-ı Siyasi-yi Ulemâ-yı Şîa der Asr-ı Kâcâr. Kum: Müessese-i Bustân-1 Kitab, 1390/2011.

İğde, Muhyettin. Siyasi-İtikadi Bir Mezhep Olarak Hanbelîliğin Teşekkül Süreci. İstanbul: Marmara Ü. İlahiyat Fakültesi Vakfı (İFAV), 2016.

İlhan, Avni. "Şia'da Usulü'd-Din”. Tarihte ve Günümüzde Şî̀lik Sempozyumu. 409-433. İstanbul: İSAV Yayınları, 1993.

İşcan, Mehmet Zeki. Muhammed Abduh'un Dini ve Siyasi Görüşleri. 2. Basım. İstanbul: Dergah Yayınları, 1998.

İşcan, Mehmet Zeki. “Selefîliğin İhyacıllı̆̆ ve Dini Düşüncede Yenilik". Marife 9/3 (2009): 9-20.

İşcan, Mehmet Zeki. Selefilik: İslami Köktenciliğin Tarihi Temelleri. İstanbul: Kitap Yayınevi, 2006.

İşcan, Mehmet Zeki. “Tarih Boyunca Selefî Söylem”. Eski Yeni 25 (2012): 56-64.

Karadeniz, Yılmaz. Kaçarlar Döneminde İran (1795-1925) İdari, Askeri, Sosyal Yapı ve Toplumsal Hareketler. İstanbul: Selenge Yayınları, 2013.

Kartaloğlu, Habib. "İmamiyye'de Ahbârî-Usûlî Farklılaşması: Şeyh Saduk ve Şeyh Müfîd Örneği”. Sakarya Üniversitesi İlahiyat Fakültesi Dergisi 13/24 (2011): 193-216.

Keskin, Halife. Kendi Kaynakları Işı̆̆̆ında Şia İnanç Esasları. İstanbul: Beyan Yayınları, 2000.

Khalaji, Mehdi. "The Rise of Persian Salafism”. 20 Şubat 2020. https://www.washingtoninstitute. org/policy-analysis/view/the-rise-of-persian-salafism.

Koca, Ferhat. İslam Düşüncesinde Selefilik. Ankara: Ankara Okulu Yayınları, 2016.

Koca, Ferhat. İslam Hukuk Tarihinde Selefí Söylem Hanbelî Mezhebi. 2. Basım. Ankara: Ankara Okulu Yayınları, 2011.

Koç, Mehmet Akif. “Modernleşme Sürecinde 'İran Milliyetçiliği' Yanlısı Tebrizli Bir Aydın: Ahmed Kesrevi-Hayatı, Şahsiyeti, Dünya Görüşü, Mücadelesi ve Eserleri”. Kadim Akademi SBD 3/2 (2019): 115-155.

Kutlu, Sönmez. "Çağdaş Araştırmalarda Mezhepleri ve Selefîliği Anlamaya Dair Sorunlar". İslam'ın Hakikati ve Mezhep Sorunu. Ed. Mehmet Evkuran. Ankara: Anadolu İlahiyat Akademisi, 2016.

Kutlu, Sönmez. Selefiliğin Fikrî Arkaplanı: İslam Düşüncesinde İlk Gelenekçiler. Ankara: Otto Yayınları, 2016.

Kutlu, Sönmez. Tarihsel Din Söylemleri Üzerine Zihniyet Çözümlemeleri. Ankara: Otto Yayınları, 2012.

Muhammed b. Abdilvehhâb. Keşfu'ş-Şubuhât. İskenderiye: Dâru'l-İman, t.y.

Muhammed b. Abdilvehhâb. Kitâbu't-Tevhîd. 5. Basım. Kuveyt: Mektebetu Ehli'1-Eser, 1435/2014.

Müsteân, Hüseyinkulî. "Mukaddime". Mahvu'-Mevhûm. Şerîat Senglecî. Tahran: Çaphâne-i Tâbân, 1944.

Nafi, Beşir M. “Selefîliğin Kavram Sorunsalı, Tarihi ve Muhtelif Görünümleri”. Arap Dünyasında Selefilik ve Selefi Hareketler. İstanbul: Yarın Yayınları, 2016.

Nafi, Beşir M.-Abdu'l-Mevlâ, İzzuddîn-Takiyye, el-Havvâs, ed. Arap Dünyasında Selefilik ve Selefí Hareketler. Trc. Nurullah Çakmaktaş. İstanbul: Yarın Yayınları, 2016.

Râgıp el-İsfahanî, Hüseyin b. Muhammed. Müfredatu Elfazil-Kur'ân. Beyrut: Dâru'1-Kalem, 1412/1992. 
Rahmâniyân, Daryuş. "Nigahî be Seyr-i Teceddud der İan (Ez Abbas Mirza tâ Emir Kebir)". Mecelle-yi Coğrafya ve Bernâmerîzî 16 (1383/2004), 55-74.

Rezevî, Mikdad Nebevî. "Nigâhî Tahlîlî be Tekâpûhâ-yı Fikrî-yi Şerîat Senglecî”. Faslnâme-i İmâmet Pejûhî 1/4 (1390/2011): 249-271.

Rıdvânî, Ali Asgar. Selefigerî (Vehhâbiyet) ve Pâsoh be Şubehât. 9. Basım. Kum: İntişârât-1 Mescid-i Mukaddes-i Cemkerân, 1393/2014.

Rüstem, Sa'd. Zindegînâme-i Muslih-i Kebîr ve Allâme- i Şehîr Âyetullah Şerîat Senglecî. İntişârât-1 Akîde, 1393/2014.

Selîm, Muhammed Nebî. "Berhî Cereyânhâ-yı Dîgerendîş der Asr-1 Pehlevî”. Faslnâme-i İlmî Pejûhişî-yi Târîh 2/6 (1386/2007): 75-117.

Senglecî, Şerîat. Kilîd-i Fehm-i Kur'ân bi-İnzimâmi Berâhînil-Kur'ân. B.y.: y.y., 1395/2016.

Senglecî, Şerîat. Mahvu'-Mevhûm. Tahran: Çaphâne-i Tâbân, 1944.

Senglecî, Şerîat. Tevhîd-i İbâdet (Yektâperestî). 3. Basım. b.y.: y.y., 1386/2007.

Sinanoğlu, Mustafa. "Şirk". 20 Şubat 2020. https://islamansiklopedisi.org.tr/sirk.

Şahin, Hanifi. "İhya Islah Hareketleri ve Selefîlik İrtibatı”. e-Makâlât: Mezhep Araştırmaları 9/1 (2016): 1-37.

Şahrızâyî, Ali Tasdîkî-Müeddeb, Seyyid Rıza. “Nakd-i Dîdgâh-1 Reveş-i Tefsîr-i Kur’an be Kur'an, Kur'aniyân-1 Şîa”. Dovre 28 (1393/2014), 1-16.

"Şerîat Senglecî". 20 Şubat 2020. https://islamhouse.com/fa/author/263776/.

Taberî, İhsan. "Şerîat Senglecî". 27 Aralık 2019. http://www.rahetudeh.com/rahetude/Tabari/ iran-rezashah/html/jameehiran-11.html.

Tehrânî, Ağa Bozorg-1. Musannefât-ı Şîa. Meşhed: Âsitan-1 Kuds-1 Rezevî, 1372/1993.

Tevâî, Fâtıma Emânî. "Şerîat Senglecî". 20 Şubat 2020. http://pajoohe.ir/\%D8\%B4\%D8\%B1\%DB\%8C\%D8\%B9\%D8\%AA-\%D8\%B3\%D9\%86\%DA\%AF\%D9\%84\%D8\%AC\%DB\%8C a-46988.aspx.

Tığlı, Asiye. Irran'da Entelektüel Dini Düşünce Hareketi. İstanbul: Mana Yayınları, 2018.

Tunç, Mazhar. Suud Selefiliğĭ, Hadis İlmi Bağlamında Bir Araştırma. İstanbul: İz Yayıncılık, 2018.

Tunkabûnî, Abdulvehhab Ferîd. İslam ve Rec'at. Tahran: İntişârât-1 Akîde, 2015.

Uyar, Mazlum. İmamiyye Şiası'nda Düşünce Ekolleri: Ahbarilik. İstanbul: Ayışı̆̆ı Kitapları, 2000.

Uyar, Mazlum. “Pehlevî Hânedanlığının Kuruluşu ve Rıza Şah Dönemi (1921-41) Devlet Ricâli-Ulemâ Münasebetleri”. Din Ĕ̆itimi Araştırmaları Dergisi 17 (2006): 173-201.

Uyar, Mazlum. Şî̂ Ulemânın Otoritesinin Temelleri. İstanbul: Kaknüs Yayınları, 2004.

Wagemakers, Joas. "Salafism". Oxford Religion Encyclopedias. 18 Şubat 2020. https://oxfordre.com/ religion/view/10.1093/acrefore/9780199340378.001.0001/acrefore-9780199340378-e-255.

Wielandt, Rotraud. "Main Trends of Islamic Theological Thought from the Late Nineteenth Century to Present Times". The Oxford Handbook of Islamic Theology. Ed. Sabine Schmidtke. Oxford: Oxford University Press, 2016.

Wiktorowicz, Quintan. "Anatomy of the Salafi Movement". Studies in Conflict \& Terrorism 29/3 (2006): 207-239. https://doi.org/10.1080/10576100500497004.

Yann, Richard. "Shari'at Sangalaji: a Reformist Theologian of the Rida Shah Period". Authority and Political Culture in Shiism. Ed. Said Amir Arjomand. New York: State University, 1988.

Yılmaz, Mustafa Selim. “İslami Düşünce Tarihinde Bir Anlama Biçimi Olarak Selefîlik Üzerine Bir Deneme". Insan ve Toplum Bilimleri Araştırmaları Dergisi 3/3 (2014): 532-553. 
